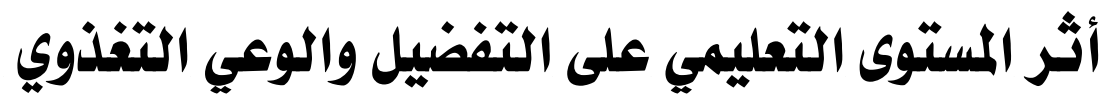

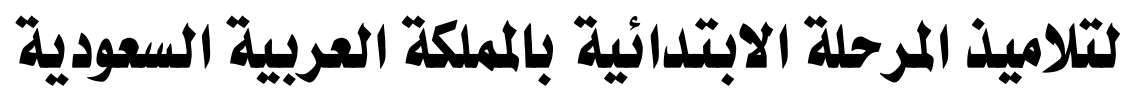

\author{
سوزلنمحمد مطابر الزلا،، ماريةطالبسالم الزهرلي
}

ققم التغنية وعلوم الألعمة، كلية التربية للاقتصاد المذزلي، مكة المكرمة، المملكة العربية للسعودية

الملخص

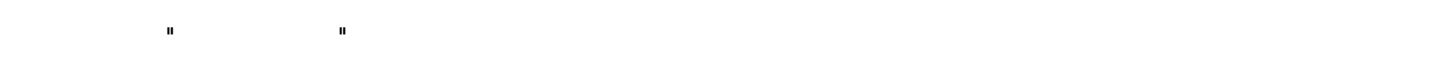

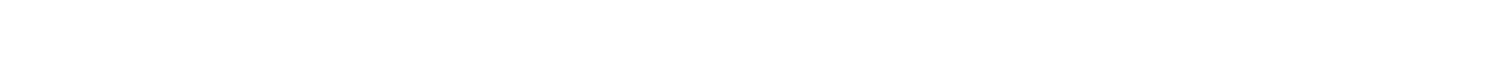

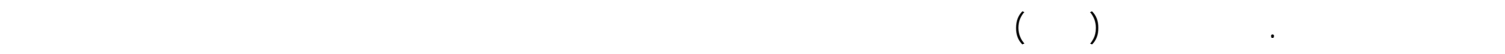

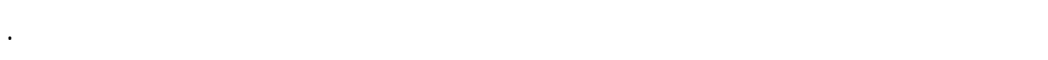
لوحظ من التحلل الإحصائي وجود تجانس كبير بينطلبة وطالبت المداس الحكومية والأهلية حيث لم قاهر ألية فروق معنوية

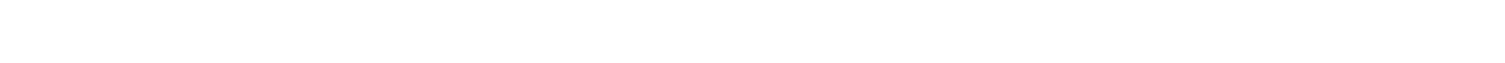

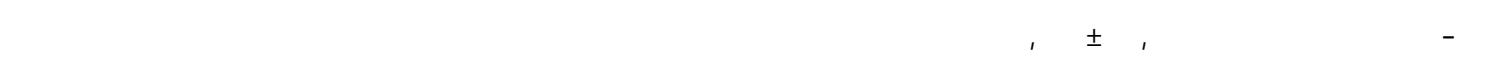

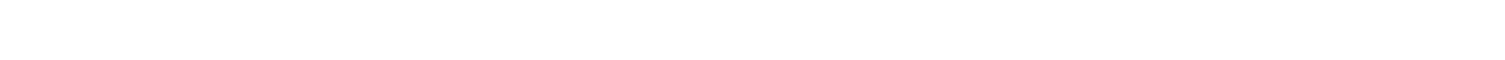

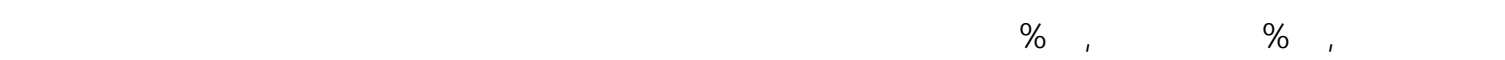

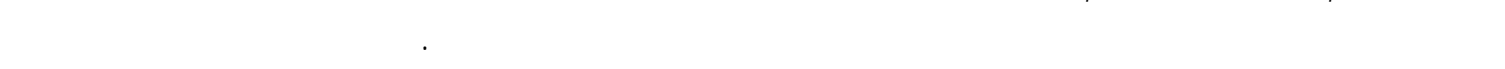

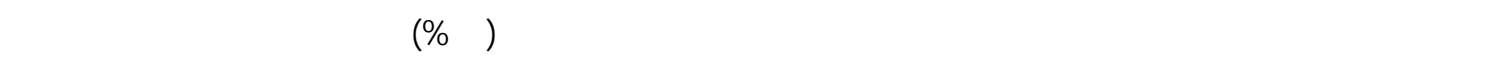

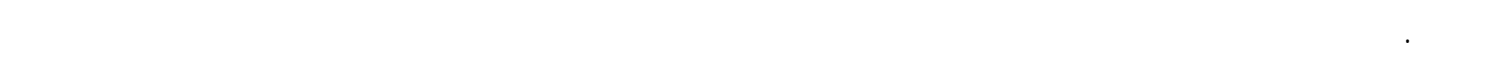

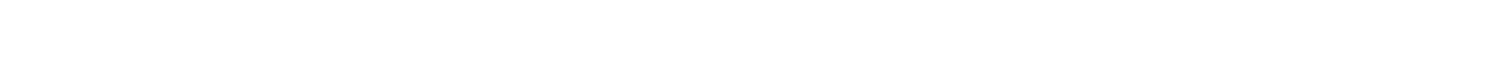

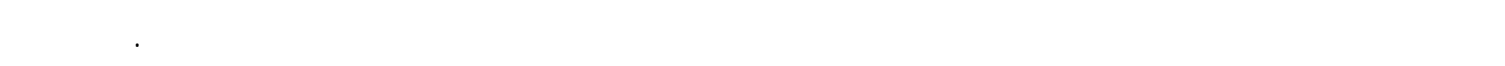

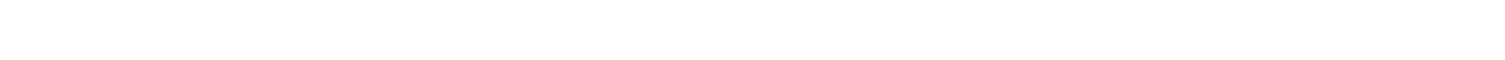

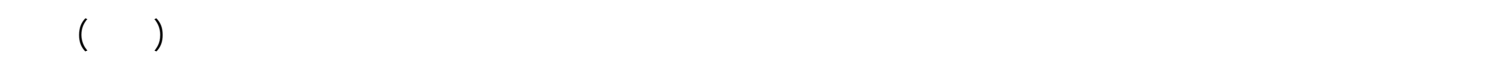

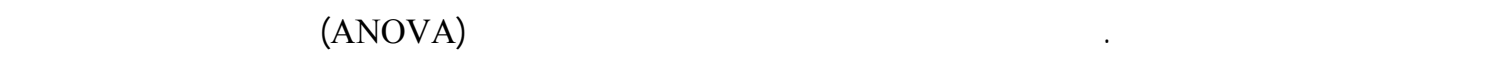

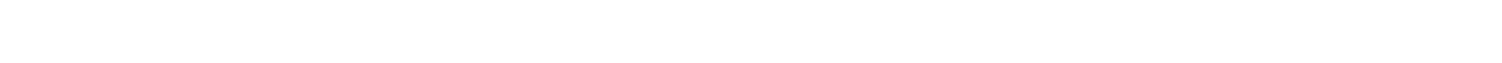

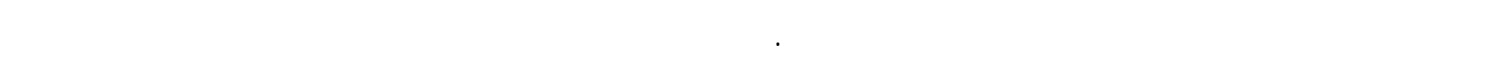

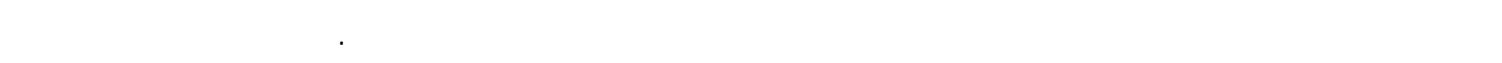

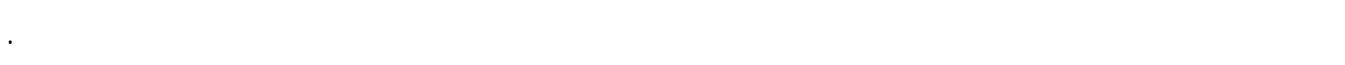

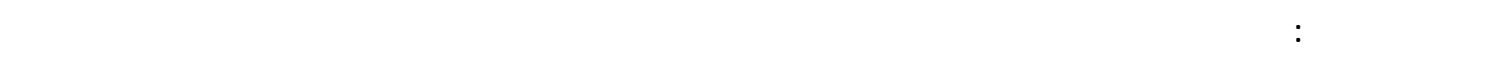
المستوى القالي، مستوى الملى.

الإنسلن على الحد الأنف من المعرفة المتكلملة وإلقان

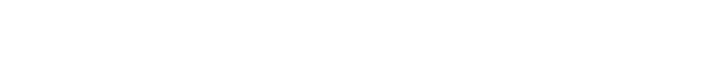

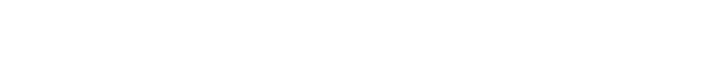

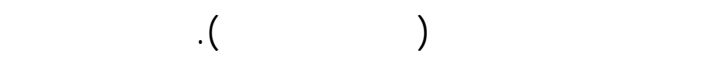

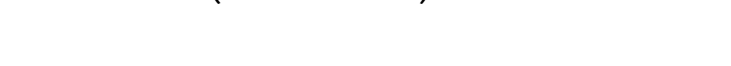

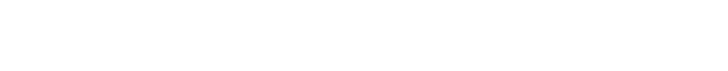

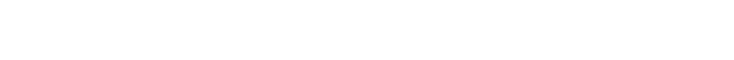

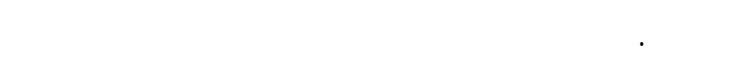
في إمسلب الطفل العادت الصحية للسليمة في المألكل

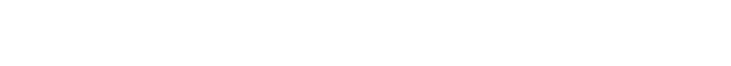

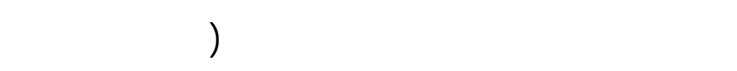

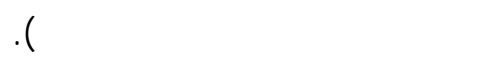

\section{المقدمــــــــا}

الألفل هه عماد المسقل لأي مجتمع من المجتمعات

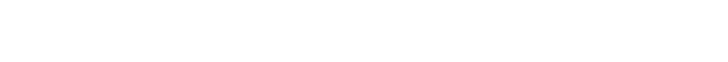
والظور، وكل دولة تخطط وترسم وقفكر من لُبل الأجيل

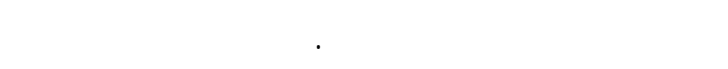

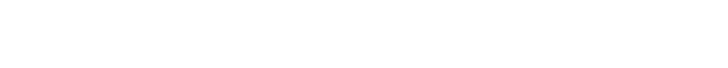

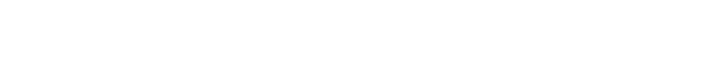

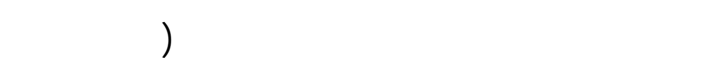

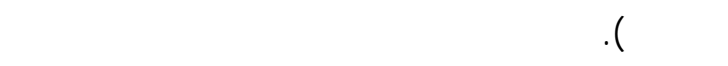

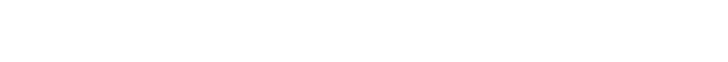

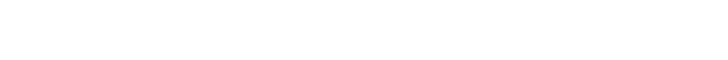


(ع - ־م) أن هناك العديد من الأسباب التي تقؤي إلى إلى

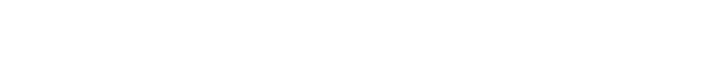

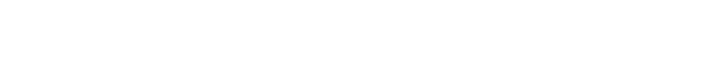
وممارسة التلميذ لبعض العادات الغذائية غير السليمة

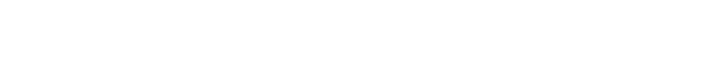

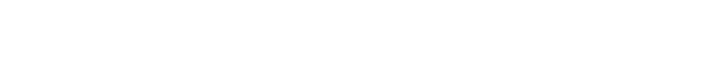

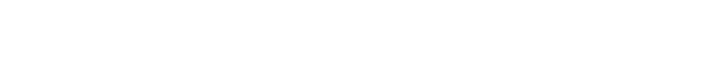

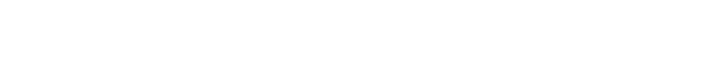

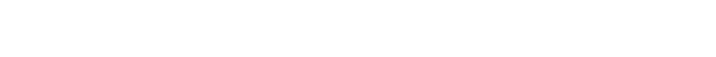
(99V)

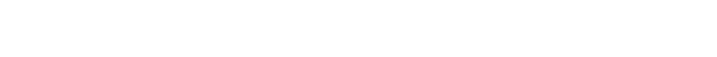

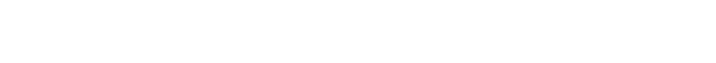
الدرلسلت أن ارتفاع المستوى التعليمي للأبوين زاد من الأني

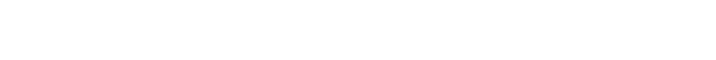
بالبروتين الحيواني مل اللحوم والأسمك والفوله والجاج. ولقد لظٔهرت درلسة لستهدفت نقيم الحالة التغذوية

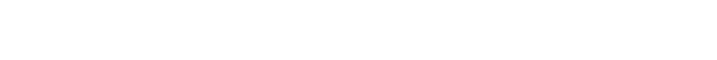

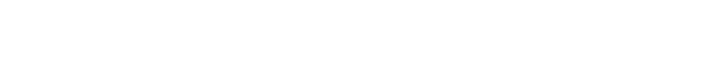

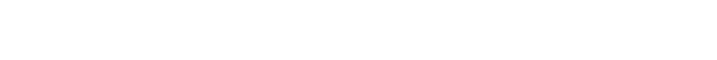

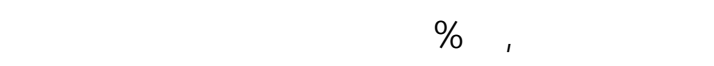

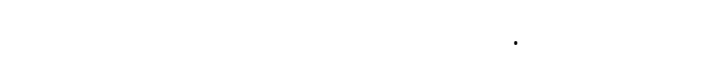

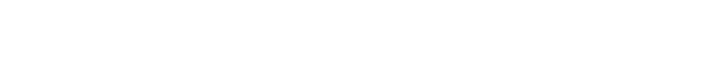

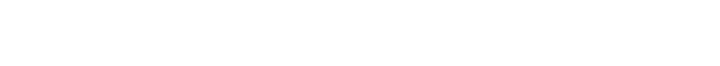

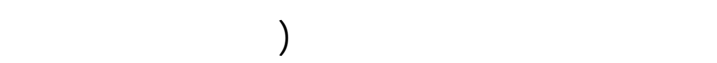
r إع (ه -).

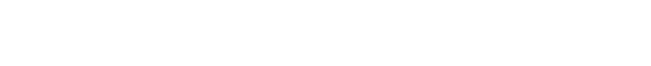
أعدت مؤسسة التغنية البريطانية بررنلمجا متكلملا للألفال

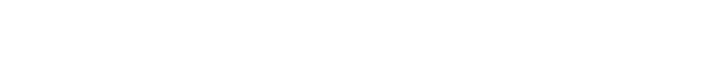

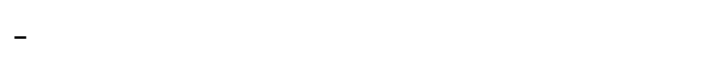
11

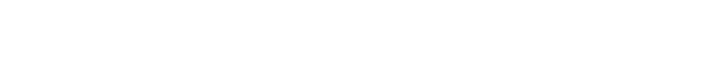

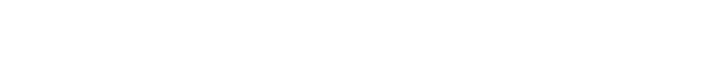

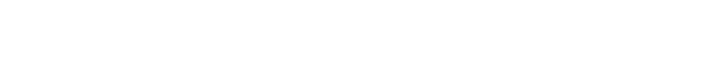

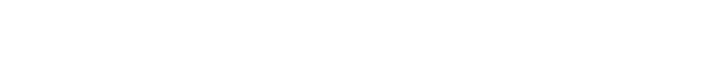

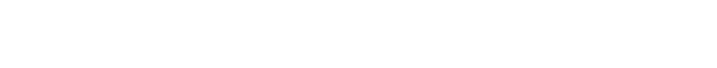
لأسبب ذلك (مجلة عالم الغذاء، ع ع - "م) . وخلصت توصيت اللقاء العلمي اللسنوي الرايع

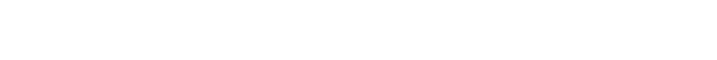

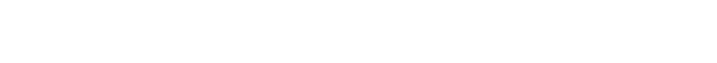

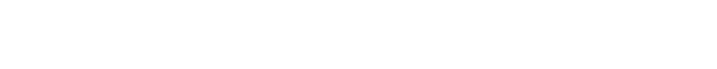

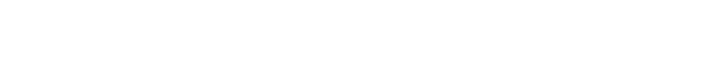
الدرلمية متضمنا التربية الغذائية والتركيز على المفاهيم
ويؤكد الثهري (ب . - مّ) أهمية دور المدبسة في

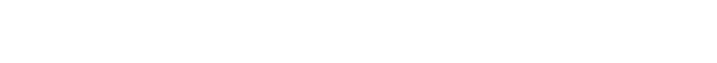

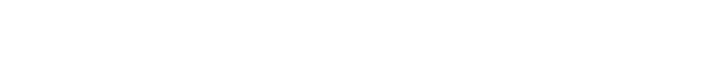

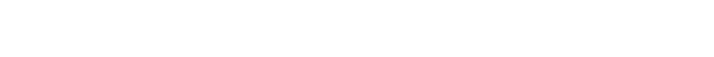

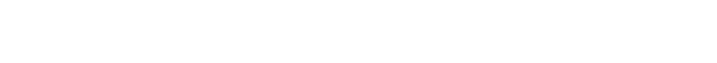

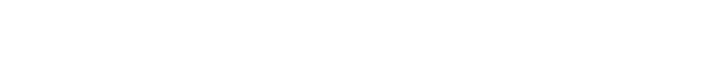
والحلويت. ويساهم التقف التغذوي في تتجنب المشلكل

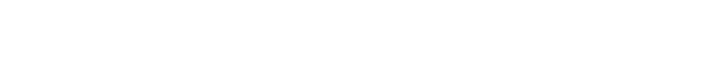

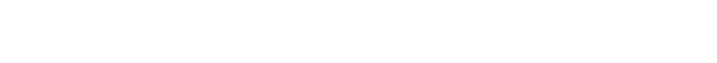

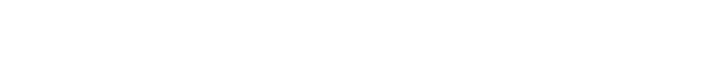
بلمراض القلب وللسرطان والجلطلت القلبية والماغية، ولقد أشارت الدرلسلت أن التقف التفلئ التغذوي والإفار

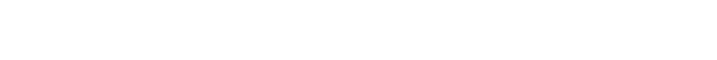

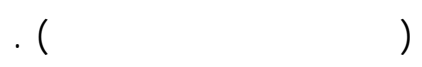

ويهم التقف التغذوي بالتغيرات التي تحدث في وني معرفة ومشاءر وسلوك النلس، وهو يركز في ألكثر أشكاله

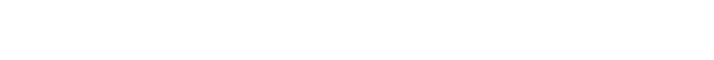

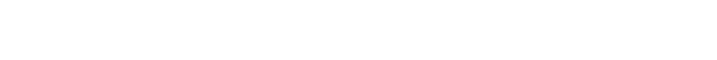
التقف التغذوي تشفل المعرفة والاتجاهلت ولمجن ولسلوك (مصيقر، 99 ام) . وتعتبر فترة الطفولة أهم ولمسرع فترة

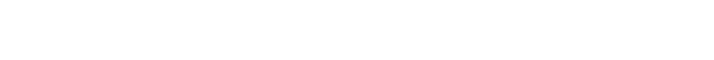

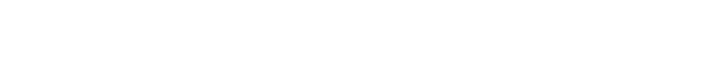

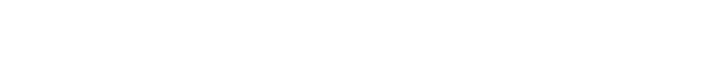

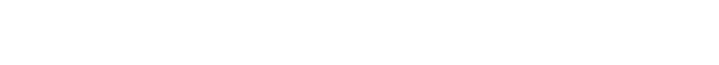

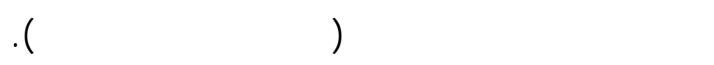
وكما هو معلوم فإن الطفل يولد ولديه لستعداد للتعلم والقط مختلف المعلوملت والعادات ومنها العادات

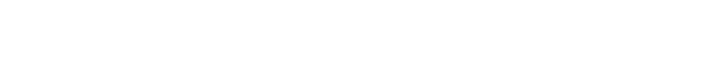

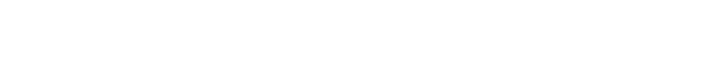
تزداد هذه العادات بسوخا ويصعب أوغير تنغييرها، وهنال وهنا يأتي

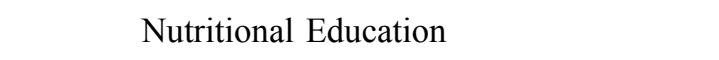
أن تبدأ في مرحلة مبكرة جداً لتعليم الطفل العادات الغذائية

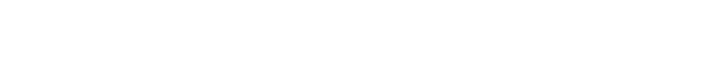

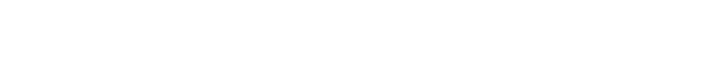
سليمة، والهذف من هذا التغيير هو تعليم الطفل كيف وليف يختار غذاءه المتوازن دون أن يبنل أي مجهود (البوفلاسة والمعضاوي، 999 ام).

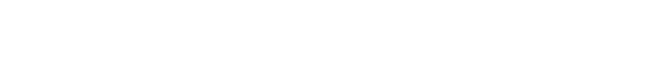

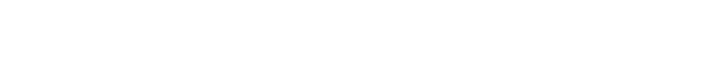

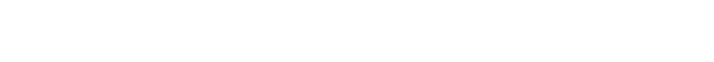

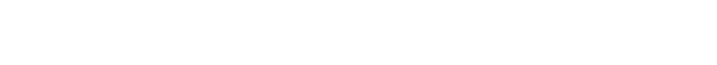
العادات الغذائية الصحيحة منذ الصغر، وتؤكد صبحي لفي 
ويستخدم القرع العسلي عادة في العديد من البلدان

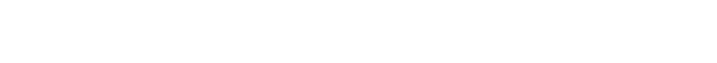

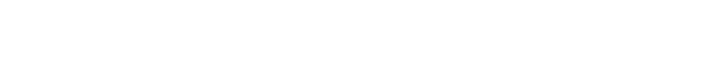
كمثروب في صور مختلفة، ويستخدم الدقيق المستخلص النه

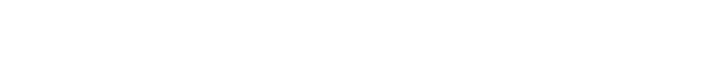
القرع العسلي والكيك والخبز بالإضلفة إلى أغذية الألفل

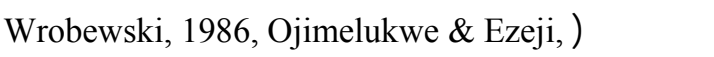
(1993, Rodriguez, 1999 إلى أن هناك العديد من الأغذية لم تجد الاهتملم الكافي

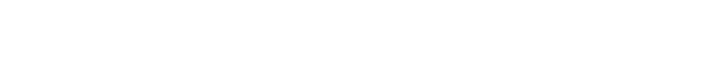

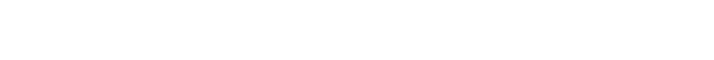

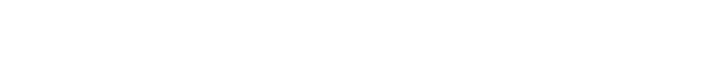

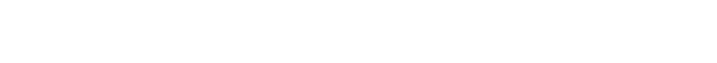

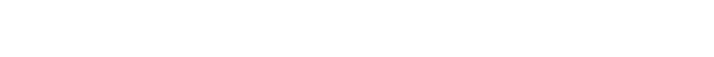

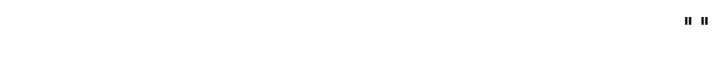
كما تحتوي على r الملجم من فيتلمين "ج ـ"، وعالمالجه من البوتلسيوم.

وظارَ لأن القرع العسلي ينتج بكميت لا بلأس بها بالمملكة العربية اللسعودية بالإضفافة إلى رخص الهم ثمنه

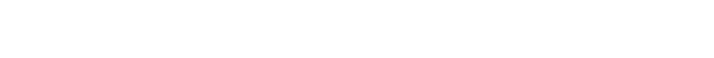

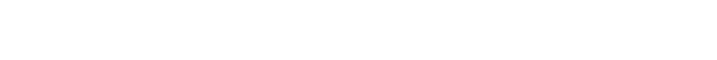

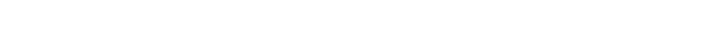

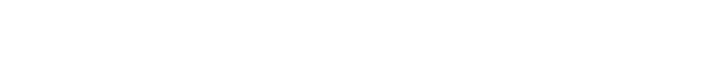

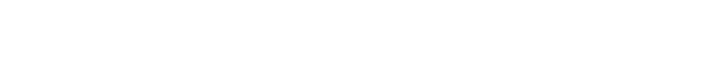
يستدعي إمداهه بالعديد من الفيتلمينات والأملاح المعنية المينية

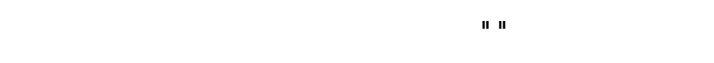

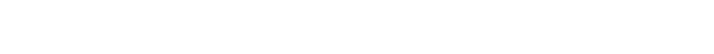

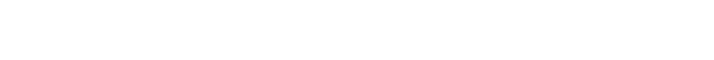

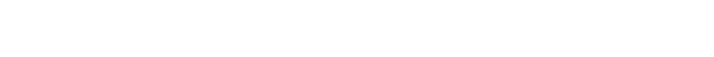

الطعلم. لذا تمثلت مشكلة البحث في التساؤلات التالية :

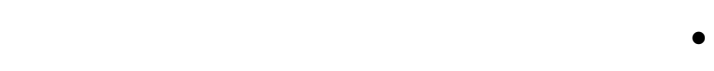
التغذوية لعينة البهث؟

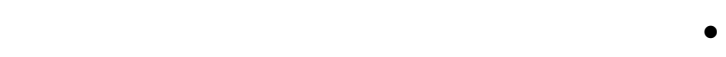
عينة البحث لنوعية الوجبة الغفية المتناولة؟

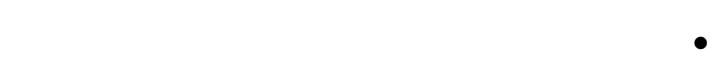
الوجبة الخفيفة المتناولة؟ المبن

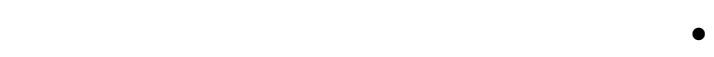
الوعي التغذوي والصسي له.

• ما هي الأطعة المفضلة لدى الأطفل ويمكن تدعيمها

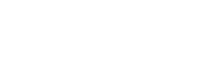
• هل هنك تقل لبعض الأصنف المختارة والمدعمة بالقرع العسلي؟

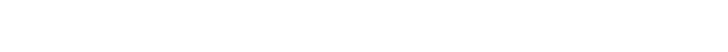
ظوير هذه المعلوملت بلستمرار. لذا فقد اعتت المبلت الملكة

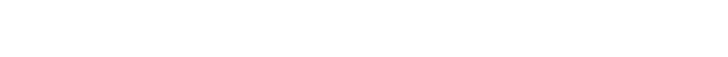
وظويرها بحيث تشهل جمبع المقررات الدرلسية الكثير من المفاهيم الصحية والتغذوية كما أعدت البرلمج المجات المختلفة

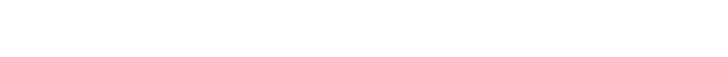
المرحلة الابتدائية في المملكة على الكثير من المفاهيد

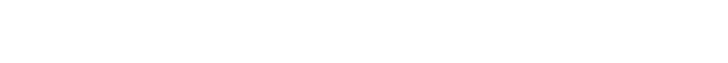

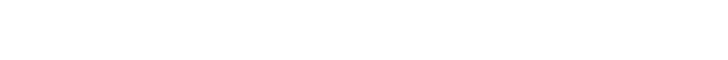

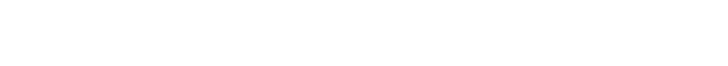
موضوعلت مبلثرة حول التربية الصحية والتغذوية، وقد الايند

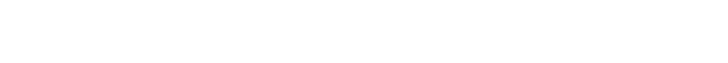
الصحة والمرض وللسلامة والغذاء المتنوع ومجموعات

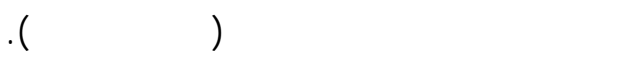

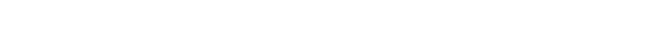

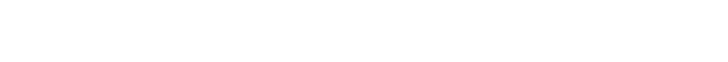

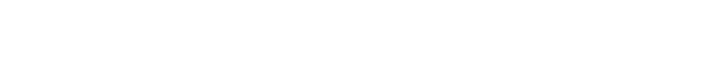

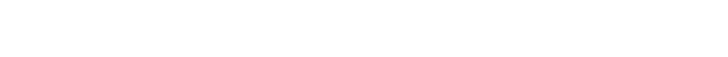

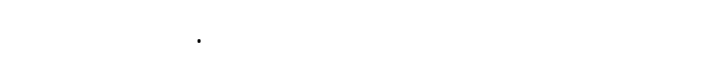

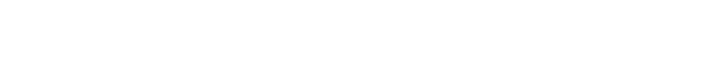

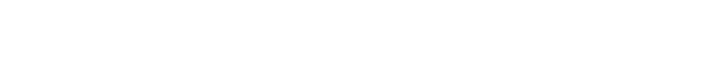

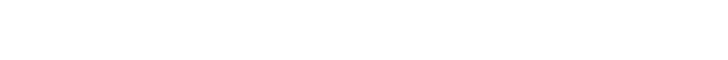
الأمراض (Powles \& Ness, 1997, Lamp, 1999;)

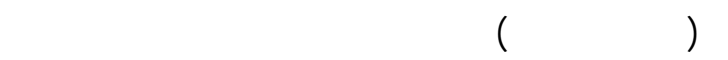

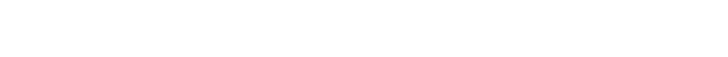

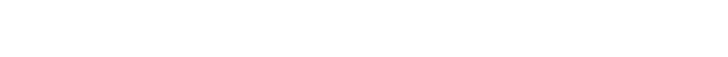

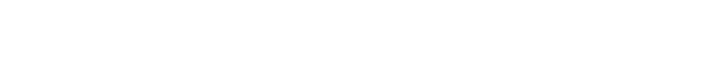

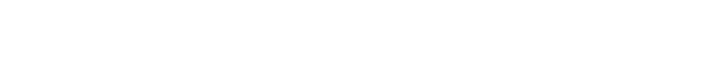

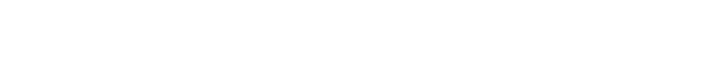

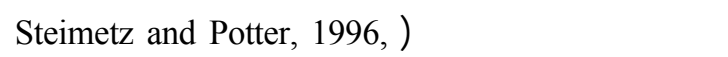
.(Desobry et al., 1998, Burri, 2003

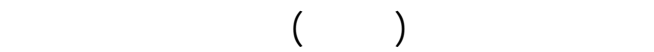

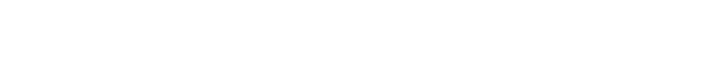

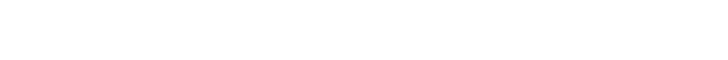

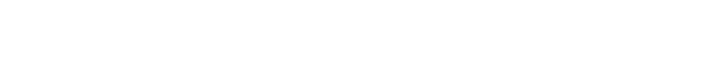

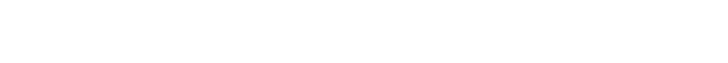

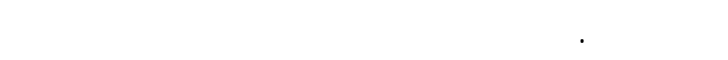

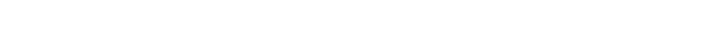

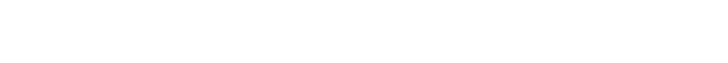

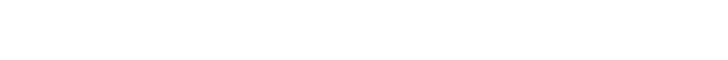

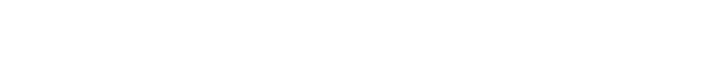

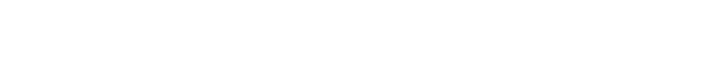


الذي تعرضت له المجموعة التجريبية، فهي أسلس الحكم (عبدات

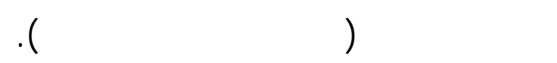

ب - عينة البهث :

ألولا - اللالبة وللالبلت: قم لختيار عينة غرضيه

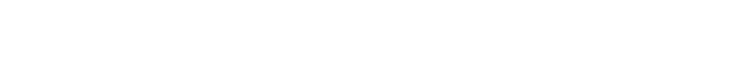
الابتدائية بالصفوف العليا (الصف الرالع والخالمس ولالساس الابتدائي) بمدينة مكة المكرمة وقد قم ققسيم تالك العينة إلى :

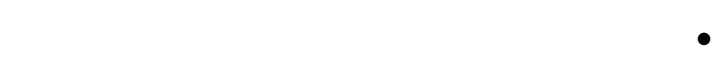

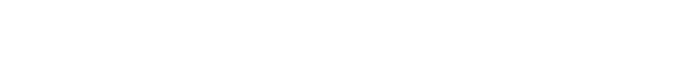
(مدرسة الإبداع الأهلية الابتدائية).

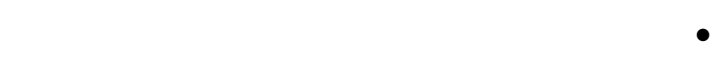

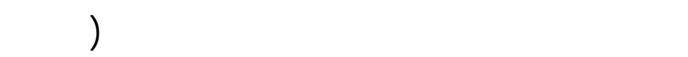
الفتلة الأهلية الابتدائية).

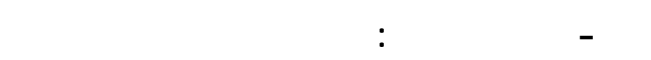

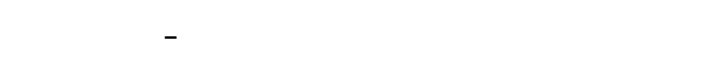
اللون البرتقالي المالل إلى الأصفر وبلغت الكمية المستعملة

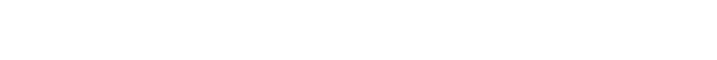

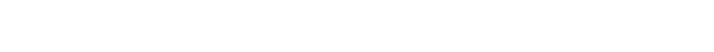

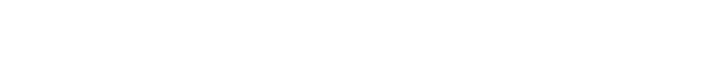
وسمك القثرة حوالي سامم، وسمك اللب حوالي مسم. ثالثا - المتذقون: قم ققيم الأصنف المقدمة من قلب

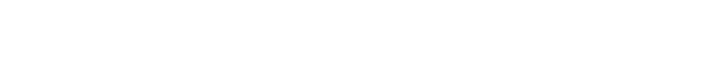
المتخصصن في التغنية وعلوم الأطعة (خمسة أعضاء

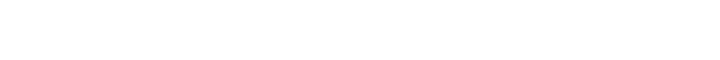

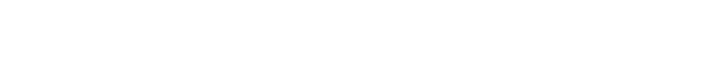

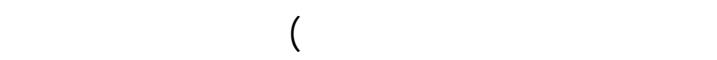

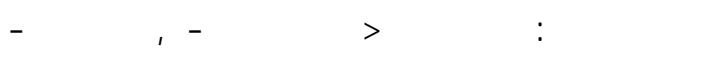

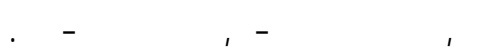

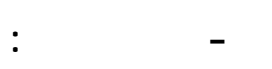

أولا - الستبلنه الجهث: يعتبر الإتبيان أو الإسقصاء

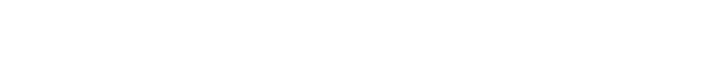

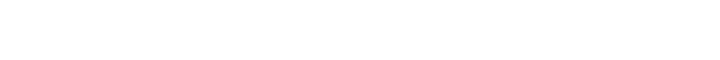
الأسئلة يلب الإجابة عنها من قبل عدد من الأفراد محل الدرلسة، وقشمل المحاور الآتية :

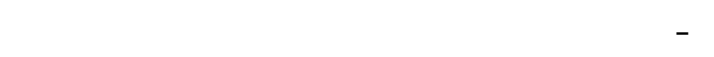

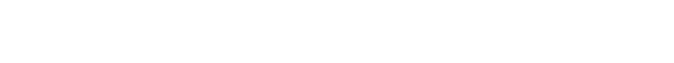
والوظيفة للأبونن وعدد أفراد الأسرة.

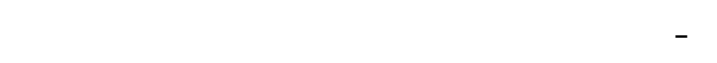
المزمنة والتي لها علاقة بالتغنية والورلثة كالإصابة بالإمسك وتسوس الأسنلن ومرض المككر والتسلسية
أهداف البحث يهزف البهث إلى : • التعرف على التاريخ الصحي لعينة البهث. • التعرف على المماسلت التغذوية لعينة البهث.

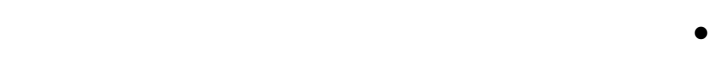

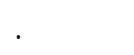

• التعرف على مدى الوعي التغذوي لعينة البهث.

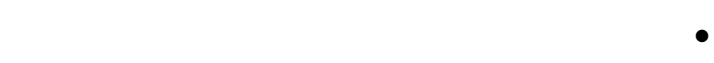
(وتشمل عساء القرع العسلي) وبعض منتجكت الخبيز

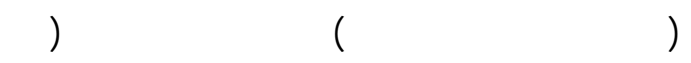
حلوى الكورن فليكس، والبسبوسة).

\section{فروض البحث}

1 - هنك علاقة بين المستوى التعليمي لكلا الأبوين والممارسات التغذوية لعينة البحث.

r - هنك ارتبط بين مستوى تعليم الأبوين ونوعية الأطعمة المفضلة لعينة البهث.

ب - هنك علاقة بين المستوى التعليمي لكلا الأبون والوعي التغذوي لعينة البهث.

ع - هنك علاقة بين المستوى التعليمي لعينة البحث ومستوى

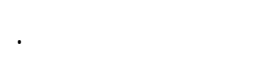

- 0 المختارة قل وبعد إضفة القرع العسلي.

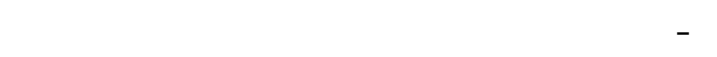
العسلي للأصنف المختارة.

\section{الأسلوب البحثي وإجراءات البحث :

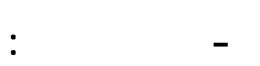

لستخدم المنهج الوصفي التحليلي الذي يعتمد على النه

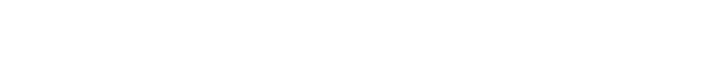

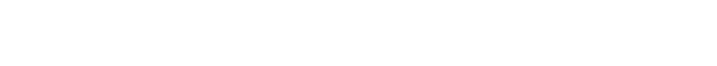
عن طريق جمع المعلوملت والبيانت كن الوضع الحالي اللحالة، والأوضاع اللساقة لها ومعرفة العوالمل التي أثرت الثرات

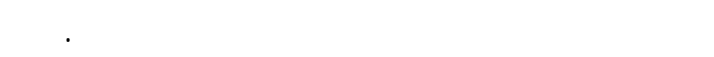

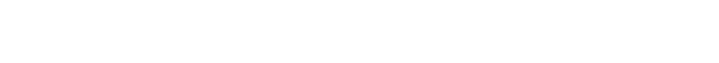

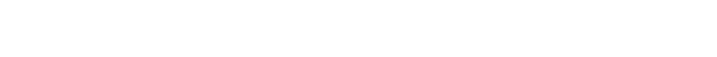

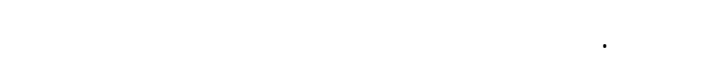

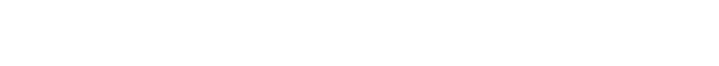

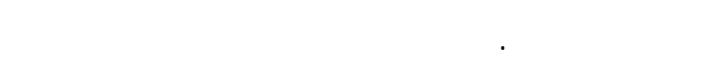

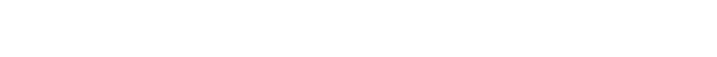

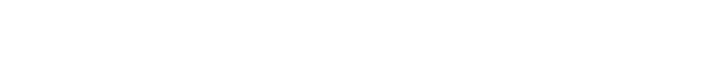
المجموعتين التجريبية والضابطة ناتجة كن المتغير التجريبي لئبي 
الدقق تدريجيا مع اللت المستمر حق تتكون عجينة لينة

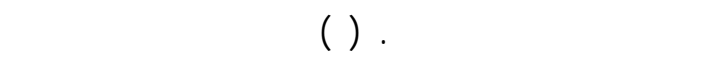
بالرقق م يوضع عليها العجين وقفرد بالنشلبة للسمك السم

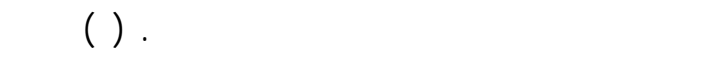
في الزيت مي ترفع وتوضع على الورق الثشلف حق آنتخلص

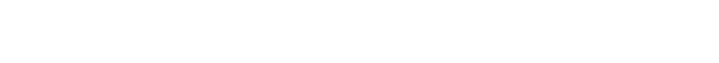
الشيكولاتة هبب الرغبة.

الككا، المقاير : كوب رقق، ثماني ملاعق كبيرة

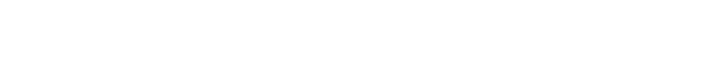

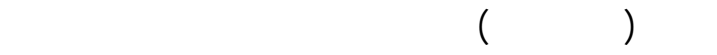

القرع العسلي المبثور، ملعقةشاي فانيليا، ذرة ملح. طرقة الهلى: (1) ينخل الدقيق ومسحوق الخبيز والملح ويوضع جانبا. (r) يخفق البيض لمدة خهس دقائق

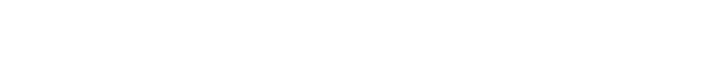

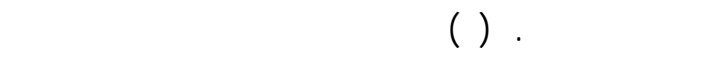
اللساق. (ع) يوضع الدقق ومسحوق الخبيز بالتدريج ويقلب حت يمتزج تملماً. (0) يوضع القرع العسلي المبشور والحليب للسائل ويمزج جيدا. (7) تبطن المن الصنئ الصينية مُ يوضع المزيج في فرن متوسط الحرارة حق ينضج.

تخرج الكعكة من الفرن وتترك حتى تبرد ويقهم. حلوى الكورن فليكس، الفالير : نصف كسيس كورن

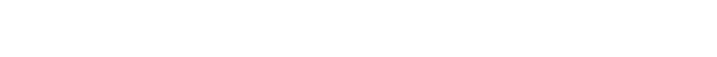

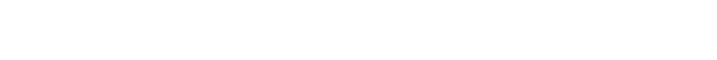

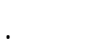

طرقة الهلى: (1) يذاب الزبد معشيكولاتة ماس لماس

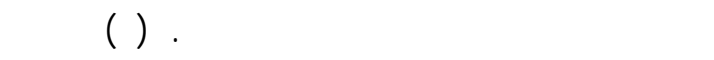
العل ومسحوق القرع للمزيج للسابق ويم الخطائ جيدا.

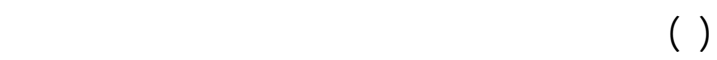

$$
\text { فليكس ويخط تملما. (ع) يشكل هسب الرغبة ويقدم. }
$$

البيتزا، المقاير: كوبان من الدقق، نصف كوب

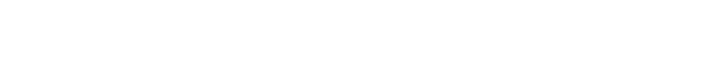
ملعقتان متوسطتان من مسحوق القرع ومبشوره. مقدارمن صلصة البيتزا (ملعقة كبيرةقسمن، ثمرتلن من الطمطم المتطعة قطعا صغيرة، جبنه موزريلا، فلفل رومي مقطع قطعا صغيرة، حلقلت من الزيتون الأسود، نصف كوب لهم عصاج، ملح وفلل لمدود، ملعقة صغيرة

$$
\text { من الثوم المطحون). }
$$

طرقة الهل: (1) تخطا المقادير الجافة وتعهل حفرة في الونط ويوضع للسمن وفرك بيطٔراف الأصانع.

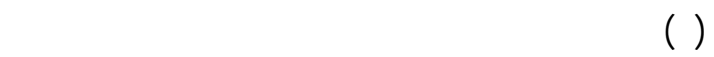
الخليط للسابق ويعبن حتى تتكون عجينة لينة متملسكة
الغذلئية ومرض الكلى ولن كلتت هنك أمراض لخرى

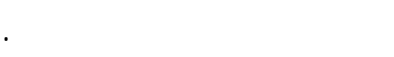

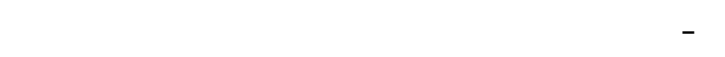
الغذلئية ومدى فضضيله لبعض الأطعمة المائعة

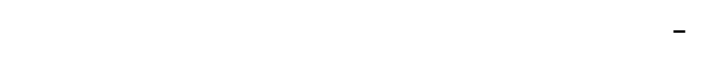
مسقلة من ماتي العلوم والتربية الونية والتبير المنزلي والتي تدرس في تاك المرحلة الدرلسية بحيث يجيب الماني

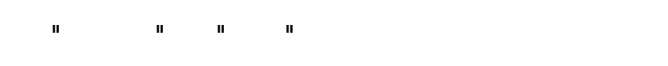
"لا أعلم" وكلن عددها خهس عثرة جملة أعليت الإجابة الصحيحة ثلاث درجلت والعبارة الخطائة "أعطيت لهات الغاليا

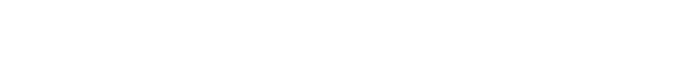

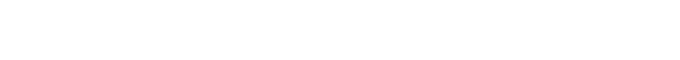

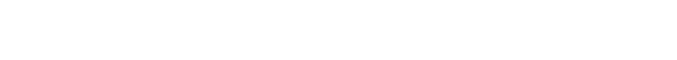

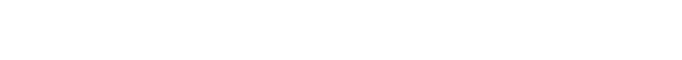

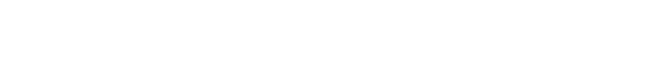
على درجك تتراوح ما بين

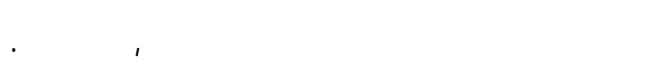

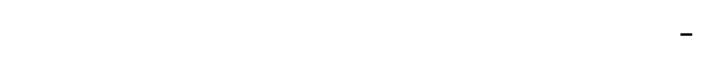

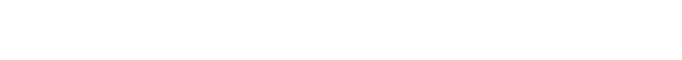

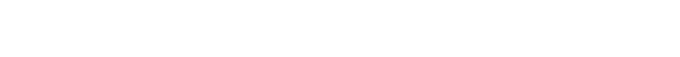

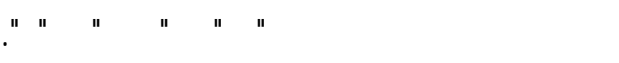

\section{ثلنيا -طربقة إعاد عينة الفرع المسلي : م غنل}

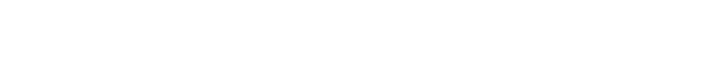

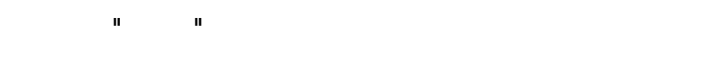

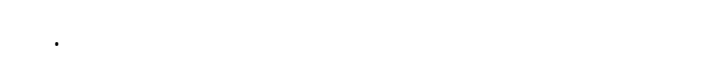

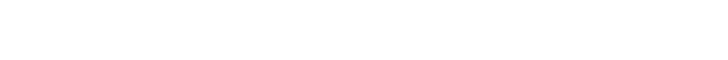

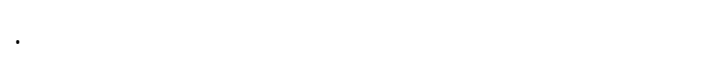

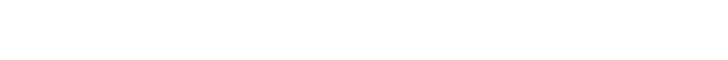

$$
\text { الدربلسة. }
$$

\section{ثالثا - طرقة على لأصناف المختارة لبلبا،}

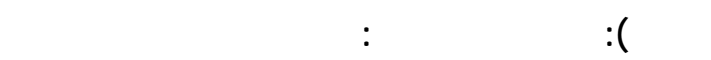

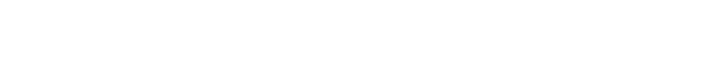

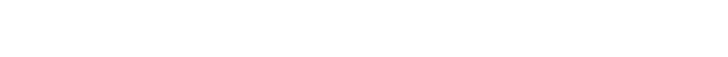

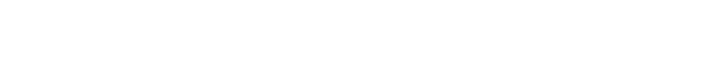
القرع العسلي. ذرة ملح.

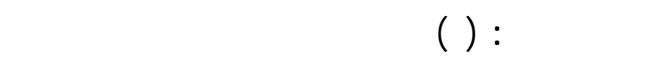
إليها الشا والملح والماء،م يضف البيض المخف المخفوق والزبد

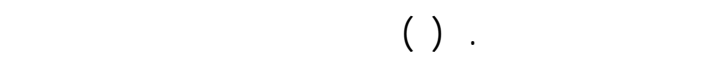
الجلف ومسحوق القرع العسلي تدريجيا مع القليب ققو

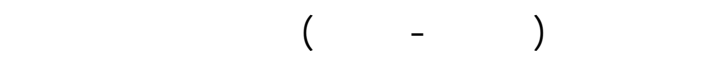
ناعمة. (ॅ) نتظف الملقة من العجينة وترفع ويضف بالقي 
• الصدق الظاهري: وفيه يكون الاختبار صارقا إذا كلن مظهره يشير إلى لنه لختبار صاق، كأن يكان يكون الفشكله

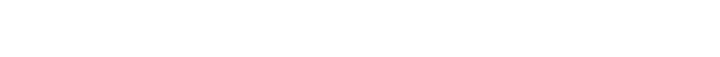

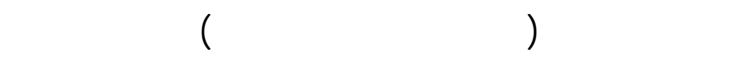

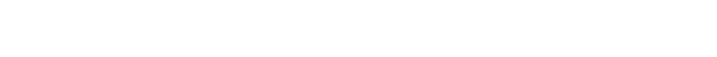

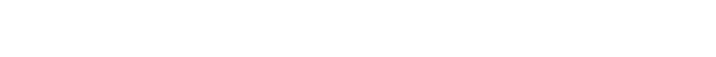

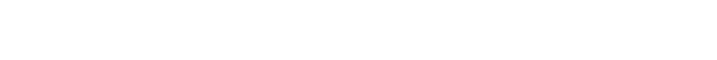

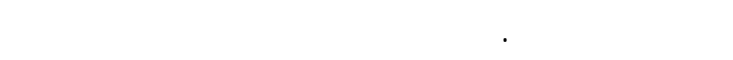
تحتاج إلى وقت زمني وخاصة مع طلبة الصف الرلعئ الابتدائي.

• تجريب الاستبيلن في صورته الأولية: حيث قم

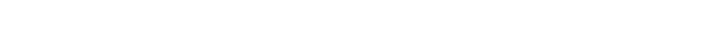

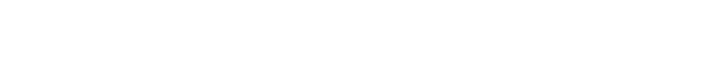

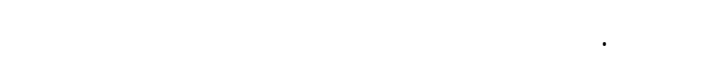
التحلل الأولى للمستبلنة.

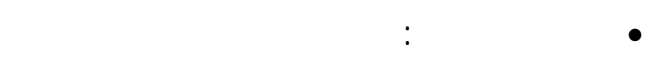

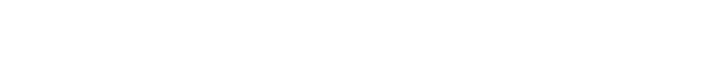

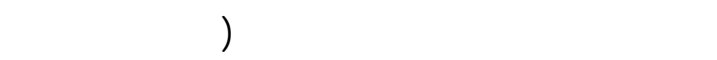

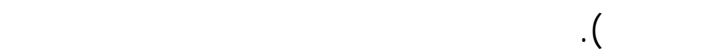
ALFA

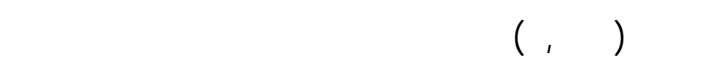
لتهقيق أغراض الدرلسة.

\section{مصطلحات البحث:}

كألفل المرحلة الابتدائية: يقسم لُٔفل مرحلة التعليم

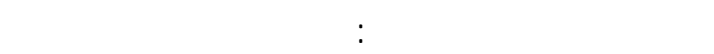

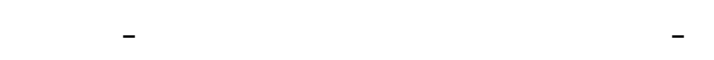
وتتميز هذه للسن ببدء الطلاق الطفل من المنزل فيصح إرضاء الأصدقاء والزملاء أهم من إرضاء الآلماء الماء والكبار،

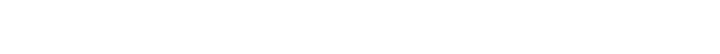

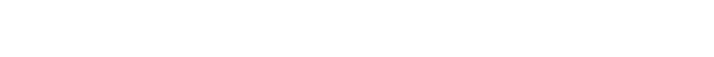

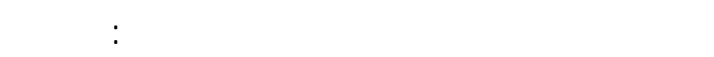
(الطفولة المبكرة) واللاحقة (المراهة المبكرة)، ويزداد المبنة

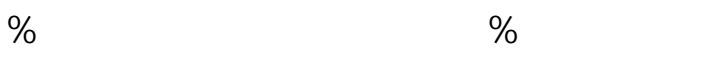
ويلاظظ حدوث طفرة في النمو في نهاية هذه المرحلة

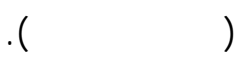

\section{التقف التغوي: يعرف التقف بأنه ثل أو لكتبل}

المعرفة والمهارت والقدرات ولسلوك والعادات وتبال الأفكار والاتجاهات والمعلوملت بين الأفراد، والتقفي

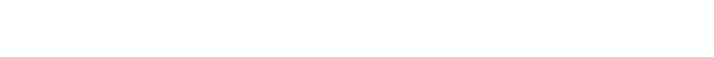
أنمطسلوكية على مستوى الفرد والمجتمع وذلك بلستخدله
تترك جولب الإناء. مُ تترك حق تتخمر. (س) فردد

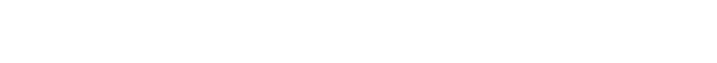
المجهزة مع مراعلة وضع مبثور القرع العسلي مع خليط

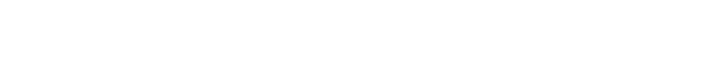

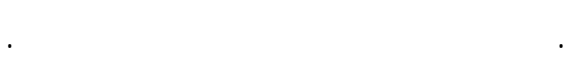

البسبوسة، المقاير: كوب سميد، علبة قثنة، نصف

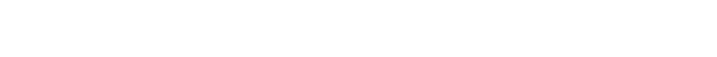

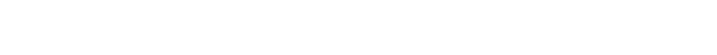
مسحوق القرع، مقدارمن المحلول السكري" للشيرة".

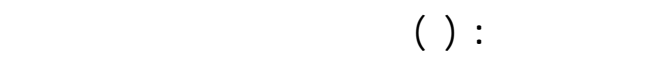

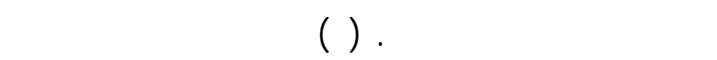

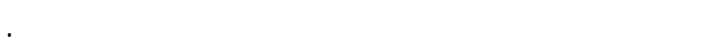

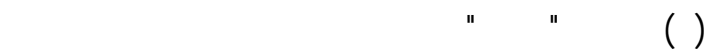
حتى تبرد وققم.

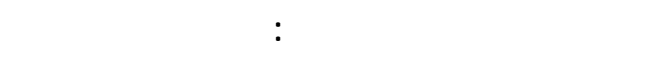

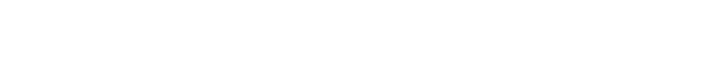

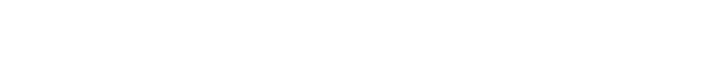

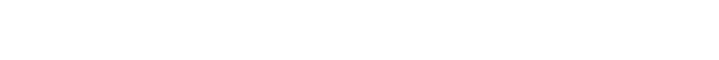
ملققة كبيرة عصير ليمون، ملح وفلنل وكمون. طرقة الملل: (1) قلب البصلة مع الزبد، ثم يضلف المالف

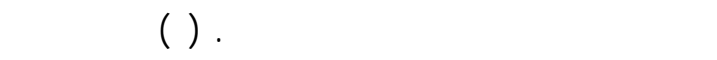
والمرق والماء والقرع العسلي والبهارات ويترك حق ينضيج.

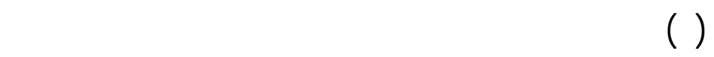
والمسحوق ويمزج جيداً. (ع) يعاد المزيج بعد خلطه إلى الم النار

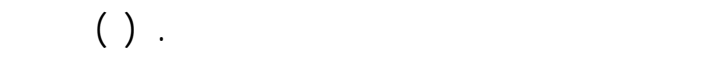

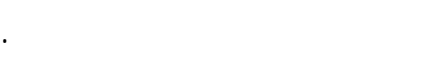

\section{التحليل الإحصائي :}

مت تحليل بيانت الاستبانة بلستخدلم برنلمج (V. 11.0)

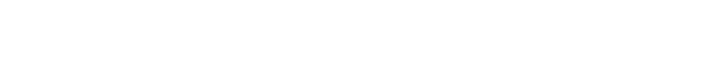
ولختبار تحليل التباين (ANOVA)، ولختبار (ت) ولختبار ALFA إحصائيا عند مستوى معنوية أقل من 0 . . . صسق وشبلت الاستبلنة: للتلكد من صدق وثبت الإستبانة مم التباع الطرق التالية:

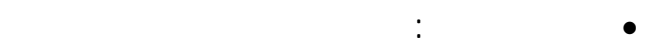

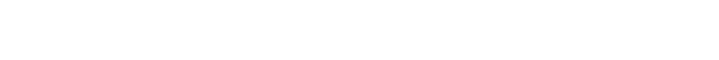

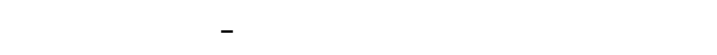
الأطعة بكلية التربية للافتصاد المنزلي بمكة المكرهة - لإبداء

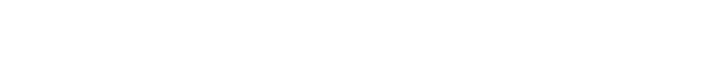
لجراء التعديلات المطلوبة وفقاً الما يظلبه البهث. 
الكاروتينوبدل: هي عبارة عن صبغلتطبيعية توجد

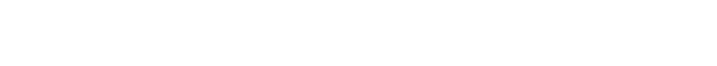

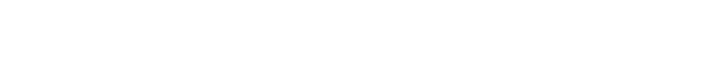

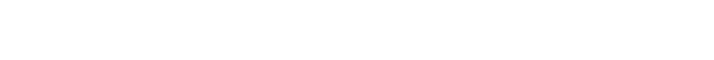
لكثر من · ج مركب من الكاروتينويدات مم التعرف عليها في الأصنف المختلفة من الفولكه والخضراوات، ويعتبر

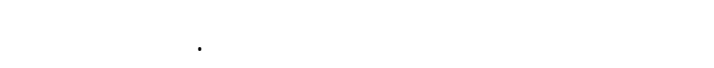
أن الإنسلن والحيولن لا يمكنهما تصنيع الكاروتينويدات ولذلك يحصلان عليها من الأطعة وهي تعمل كمضادات للأكسة (قمصاني والمدني، r. r.م). الخواص الهسية للغذاء: تعرف الخواص التسية بأنها مجموع خواص الأغنية التي يسطيع الإنسلن تحديدها

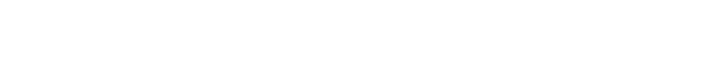

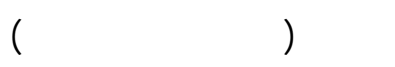

القيم الهمي: ويشطل قييم درجة القل للخصائص

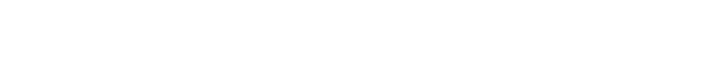
والقبل العلم، ولٔبط الطررق وأكثرهاشيوعا هو عل جداول مقنمة إلى خلنات بها وصف للعينة وتعلى درجلت رقمية متدرجة من أعلى إلى لُٔلفل الكل صفة مُ تُجمع الدرجلت وتعتمد هذه الطاريقة على الإنسلن ولجنسلسه بالنسبة للغذاء ولذا فهي تحتاج إلى خبرة وتدريب (نوار، ع - لمّ).

\section{المينة الغرضية الحصصية:}

العينة الغرضية هي التي قيوم البلمث بلختيارها

لختيارا حرا على لُسلس أنها تحقق أغراض الدرلسة. أما العينة الحصصية فهي تشبه العينة العشوائية الطقية لكنها تختلف عنها في أن البلمث يقوم بهذا الاختيار بفمسه ودون أن يلزم فسه بأيشروط (عبيدات

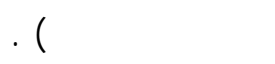

\section{أولا - لمتبانه البهث :}

قسمت عينة البهث في بادئ الأمر إلى قسمين، عينة طلاب وطالبت المداس الحكومية، وعينة طلاب ولائ لالبه

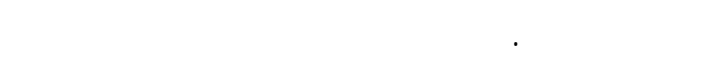

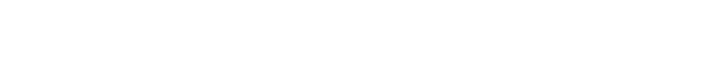
العيتتن في جمبع محاور الاستبلة. وفيما يلي لستعراضًا لتحللل النتائج:
الأساليب التربوية لتعليم الفرد كيفية حماية فهه من لمراضسوء التغذية وتغيير العادات والمعنقدات الخلطئة وتشجبع العادات الغذائية للسليمة وكذا تصحيح المفاهيم

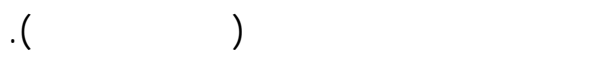
الويم التغوي والصسي: الوعي التغذوي هو

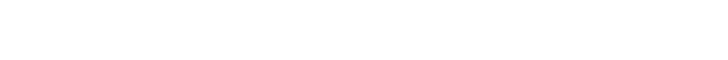

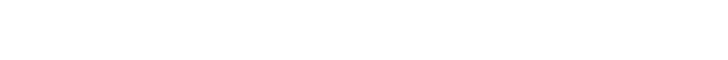
في حدود الإمكانت المنلسة (حمالل، 999 ام). أما الوعي الصحي فهو مفهوو يقصد به إلملم الموطلنين بالمعلوملت والحقائق الصحية وأن تتحول تلك الهقائق إلى فلى ممارست وعادات تمارس بلاشعور أو تقكير، ويعتبر المارية الوعي الصهي هو المماسة الصحية عن قصد نتيجة الفهر والإقناع (عبد الوهلب، 999 ام).

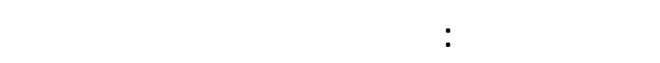
المومة التي تستخم في الوقاية وعلاج الأمراض الناتجة من

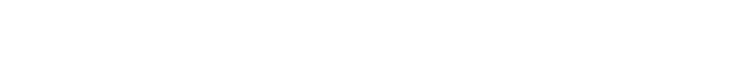

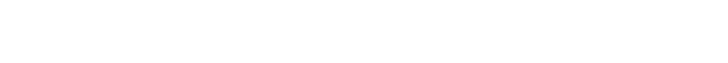

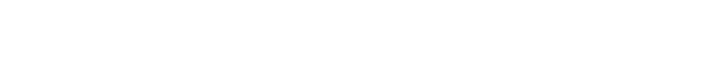

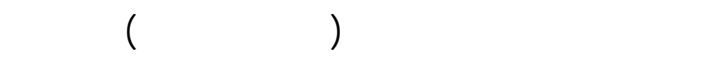

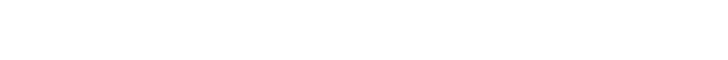

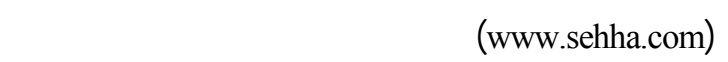

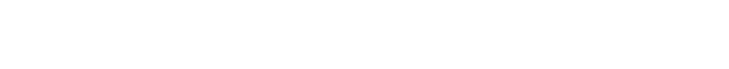

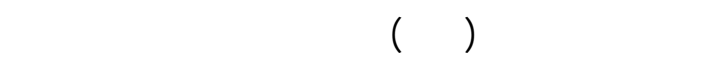

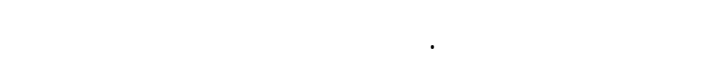

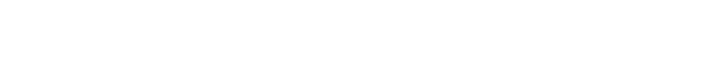

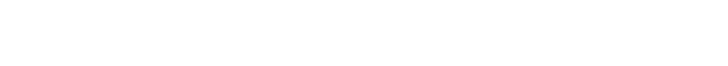

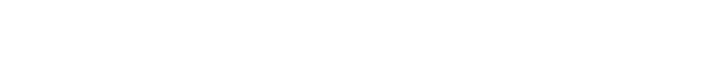
الألعمة وتناول الاضفلت الغذلئية ولخيرا التذعيم بالعناصر الغذلئية. الفرع العسلي: يعد القرع العسلي من العائلة القرعية Cucurbitaceae

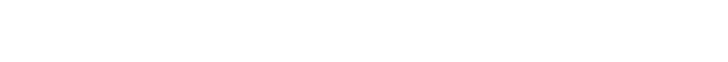

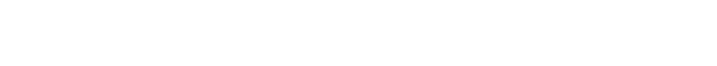
تختلف في لٔحجلمها من الحجم الصغير جدا يقل عن الحنيل

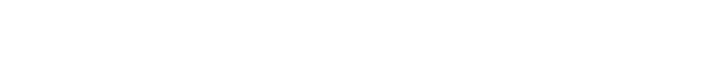

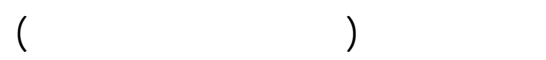




\begin{tabular}{|c|c|c|c|c|}
\hline \multicolumn{2}{|c|}{ كلل العينة } & الأمداوسة & المكومية & الدل الثهري \\
\hline$\%$ & التكرار & $\%$ & $\%$ & \\
\hline or,o & $1 \cdot 0$ & $0 \varepsilon$ & 01 & لا تعرف الدخل \\
\hline$\cdot, 0$ & 1 & - & 1 & القل من ... ب ريل \\
\hline$\varepsilon, 0$ & १ & $\varepsilon$ & 0 & 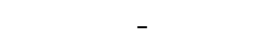 \\
\hline$\mu, 0$ & $\mathrm{v}$ & $r$ & 0 & 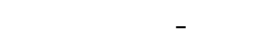 \\
\hline нq & VA & $\varepsilon$. & н & لكثرمن ·. '9ريل \\
\hline & & 1. & 1. & المجموع \\
\hline
\end{tabular}

رلباً - المستوى التعليي للأبون: يؤثر المستوى

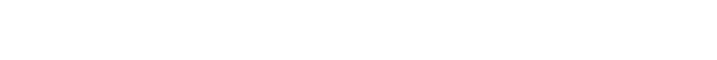

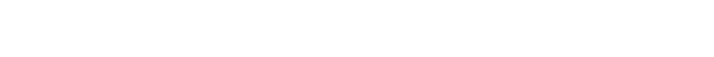

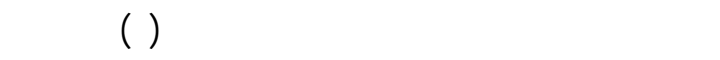

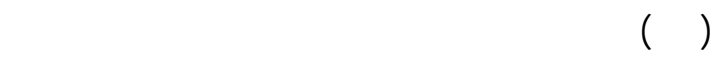

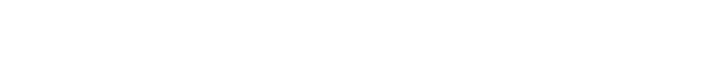

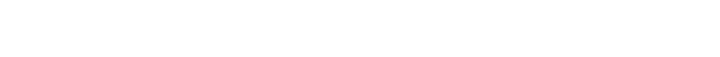
الابتدائي فتط منهم .

\section{جطل ع: توزيع أفراد العينة مسب تعليم الم}

\begin{tabular}{|c|c|c|c|c|}
\hline \multicolumn{2}{|c|}{ كلل العينة } & الأفلهاوس & المكوي & مستوى تمليم اللم \\
\hline$\%$ & الكرار & $\%$ & $\%$ & \\
\hline 10,0 & I & $1 \mu$ & 11 & أمية \\
\hline$\varepsilon$ & $\Lambda$ & 0 & $\mu$ & تتعليم البتدائي \\
\hline 1. & $r$. & 1. & 1. & تعليم متوطط \\
\hline$\varepsilon, 0$ & 9 & $\varepsilon$ & 0 & تعليم ثانوي \\
\hline 77 & rrו & 74 & $7 \varepsilon$ & تعليم جلمعي \\
\hline $1 \ldots$ & $r .$. & $1 \ldots$ & $1 \ldots$ & المجموع \\
\hline
\end{tabular}

جطل 0: توزع لفراد المينة هسب تمليم الأب

\begin{tabular}{|c|c|c|c|c|}
\hline \multicolumn{2}{|c|}{ كللل العينة } & المداوس & المكالوس & . \\
\hline$\%$ & الكرال & $\%$ & $\%$ & \\
\hline 1. & $r$. & १ & 11 & أهي \\
\hline$\mu$ & 7 & $\mu$ & $\mu$ & تعليم البتدلئي \\
\hline - & - & - & - & تعليم متوسط \\
\hline 10 & $\mu$. & I & IV & تتعليم ثلنوي \\
\hline$v r$ & |દદ & vo & 79 & تعليم جامعي \\
\hline 1. & $r$. & $1 \ldots$ & $1 \ldots$ & المجموع \\
\hline
\end{tabular}

\section{المحور الأل للسنبلنة:}

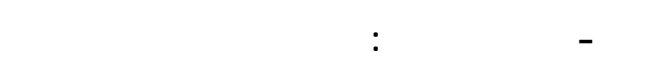

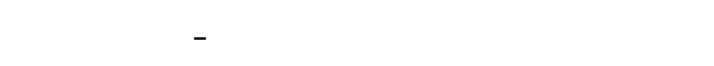

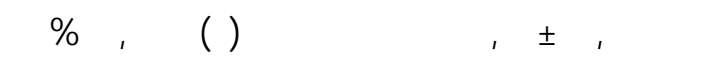
عينة البهث في المداس الأهلية قد تجاوزسن الثالثة كثرة.

جطل I : النسبة المئوبة الفئلت الهمربة لعينة البهث

\begin{tabular}{|c|c|c|c|c|c|c|}
\hline \multicolumn{2}{|c|}{ كللى العينة } & \multicolumn{2}{|c|}{ المداس الأهلية } & \multicolumn{2}{|c|}{ المكوالوس } & \multirow{2}{*}{ العمربة } \\
\hline$\%$ & الكرار & $\%$ & التكرار & $\%$ & الكرال & \\
\hline rV & VE & ro & ro & чq & нq & اسسنوات \\
\hline ו & זד & عَ" & ع & $r \Lambda$ & rA & | السنة \\
\hline$r \cdot, 0$ & (1 & r & r & 19 & 19 & rاسنة \\
\hline 11 & r & $\Lambda$ & $\Lambda$ & $1 \varepsilon$ & | & "راسنة \\
\hline$\cdot, 0$ & 1 & 1 & 1 & - & - & ع (سنة \\
\hline $1 \ldots$ & $r .$. & $1 \ldots$ & $1 \ldots$ & $1 \ldots$ & $1 \ldots$ & المجموع \\
\hline
\end{tabular}

وهذا يؤكد أن غالبية لُٔلفل هذه المرحلة الدربلسية

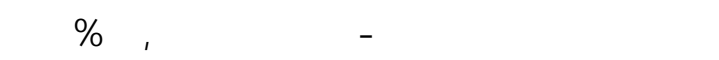

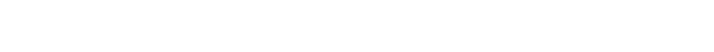
العليلمن التعليم الابتدائي.

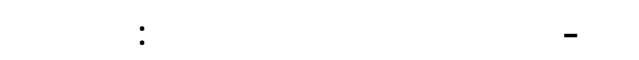

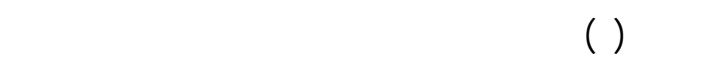
الساس يليهُ من كان ملتهقا بالصف الرليع الابتدائي.

جطل r: النسبة المئوية اللمتوى التعلي للينة الجث

\begin{tabular}{|c|c|c|c|c|}
\hline \multicolumn{2}{|c|}{ كللل العية } & الأماولية & الاككومية & \\
\hline$\%$ & التكرار & $\%$ & $\%$ & \\
\hline سب & 77 & $\mu$. & $\mu$ & الصف الرالع \\
\hline$r \varepsilon, 0$ & ६१ & rq & $r$. & الصف الخلمس \\
\hline$\varepsilon r, 0$ & 10 & દા & $\varepsilon \varepsilon$ & الصف الساس \\
\hline 1. & $r .$. & 1. & $1 \cdots$ & المجموع \\
\hline
\end{tabular}

شالثأ - المل اللثهري لعينة البهث: يعكس النخ

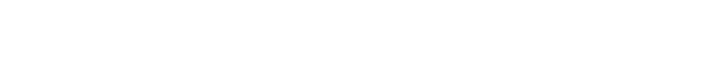

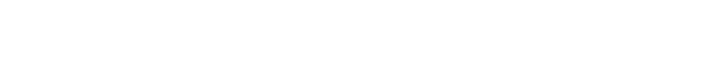

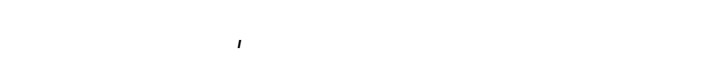

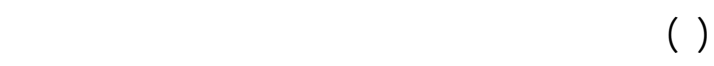

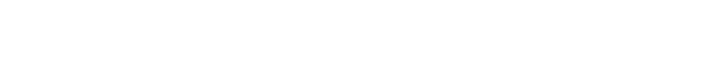

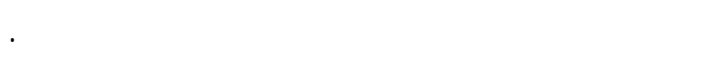

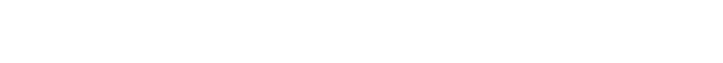

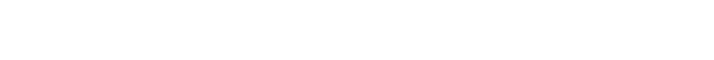

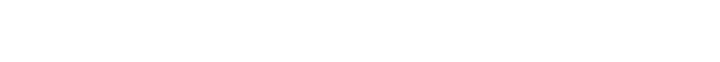
ملتحقن بالمداس الأهلية أو الحكومية. 


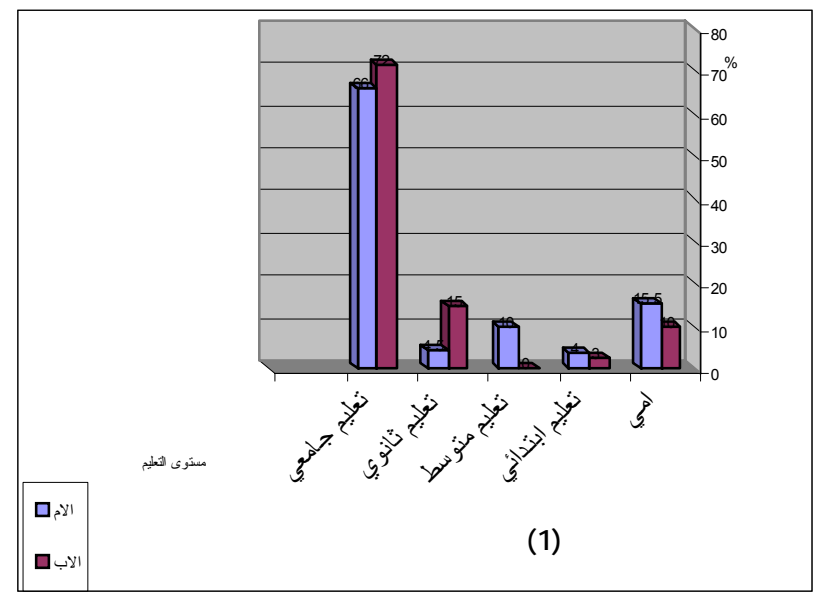

العينة من الإصابة بلاسكري وأمراض الكلى في حين أشارت إلى أن لٔثثر من ثلث أفراد العينة كلنوا مصابين بالهسلسية وتسوس الأسنلن.

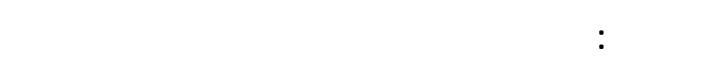
البهث

\begin{tabular}{|c|c|c|c|c|c|c|}
\hline \multicolumn{3}{|c|}{ المدالوس الأهلية (\%) } & \multicolumn{3}{|c|}{ المداوس الحكومية (\%) } & \multirow[b]{2}{*}{ المرض } \\
\hline $\begin{array}{c} \\
\\
\end{array}$ & ע & i & العلم & ע & م. & \\
\hline 1. & v7 & $1 \varepsilon$ & 11 & $\mathrm{v1}$ & r & مسك \\
\hline$\mu$ & 07 & દા & 1 & 09 & $\varepsilon$. & تسوس الأسنان \\
\hline 11 & 10 & $\varepsilon$ & $\wedge$ & $\Lambda \mathrm{V}$ & 0 & ض السكري \\
\hline 11 & 00 & ع & 1. & 7. & $\mu$. & أمراض الحسلسية \\
\hline rع & $7 \Lambda$ & $\wedge$ & 19 & $\mathrm{~V}^{\mu}$ & $\Lambda$ & أمراض الكل \\
\hline
\end{tabular}

ثلنياً - اللطل والونن: لظٔلهر التحلل الإحصائي لعينة

البهث أن هنك تجلنساً في الطول والوزن بين عينة الدرلسة

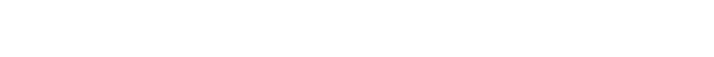

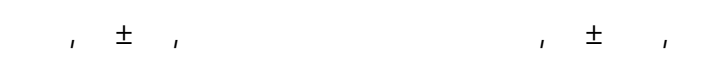

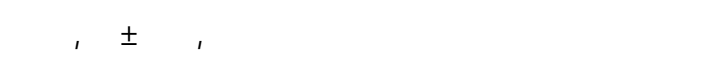

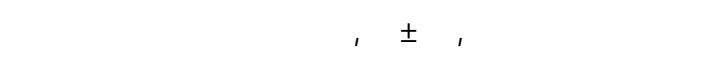

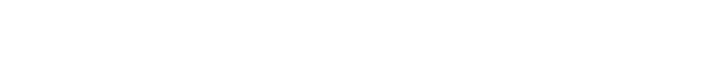
qr

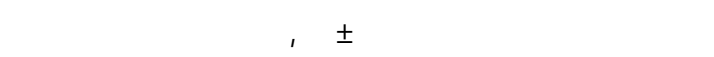
r,

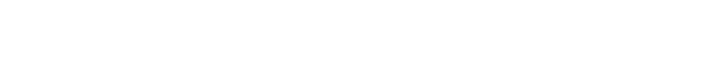
وآخرون (199\%) Osman

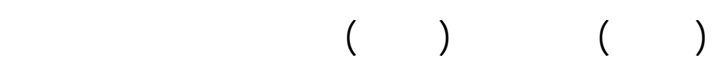

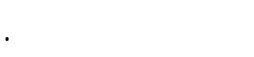

خلهسا - ولفة الوالمين: يتضح من جدولي (1) V)

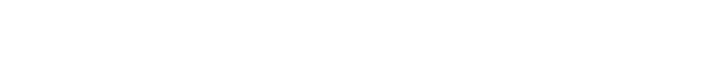

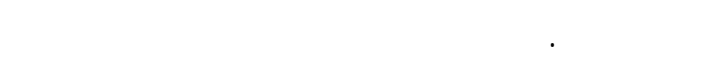

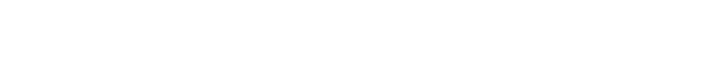
المستوى الاقتصادي للألسر. جطر 1: توزيع لفراد العينة مسب ظليفة الم

\begin{tabular}{|c|c|c|c|c|}
\hline \multicolumn{2}{|c|}{ كللل العينة } & الأفلهاوس & المكومية & \multirow[t]{2}{*}{ ظليفة الأم } \\
\hline$\%$ & التكرار & $\%$ & $\%$ & \\
\hline${ }^{\mu} \wedge, 0$ & vi & દા & ר & موظفة \\
\hline$O V, O$ & 116 & or & 71 & ربة منزل \\
\hline$\varepsilon$ & 1 & 0 & $\mu$ & مقاعة \\
\hline 1. & $r$. & $1 .$. & 1. & المجموع \\
\hline \multicolumn{5}{|c|}{ جلط V: تونع أفراد العينة مسب ظلفة الأب } \\
\hline \multicolumn{2}{|c|}{ كللل العينة } & المداوس & المداوس & \multirow{2}{*}{ ظلفة الأب } \\
\hline$\%$ & الكرلا & $\%$ & $\%$ & \\
\hline V१,० & 109 & $\Lambda$. & vq & موظف \\
\hline 1. & $r$. & 1. & 1. & أعمل حرة \\
\hline$\mu$ & 7 & $r$ & $\varepsilon$ & مقاعد \\
\hline $\mathrm{V}, 0$ & 10 & $\Lambda$ & v & لم ينكر \\
\hline $1 \cdots$ & $r$. & $1 \cdots$ & $1 \ldots$ & المجموع \\
\hline
\end{tabular}

\section{المحور الثاليمن الإستبلة:}

أولا - التاريخ الصهي لهينة الجهث : ترجع أهمية

التاريخ الصحي لعينة البهث في التعرف على مدى المعانلة

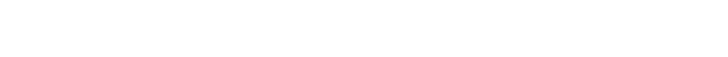
المرحلة , وقدظهر من النتائج (جدول ^) خلومظم أفراد 
وبالتالي الشعور بالثشع يشير إلى لتجه العينة لبعض

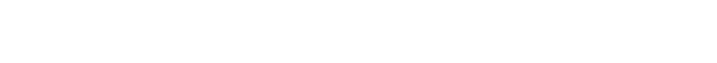
اللسريعة الغنية بالدهون بدلامن الوجبة الرئيسية باليو.

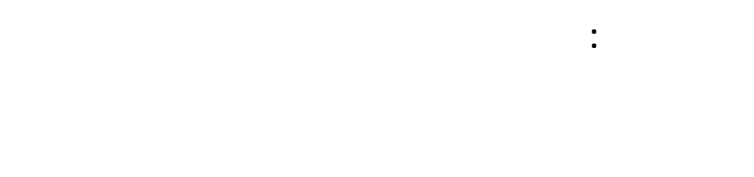

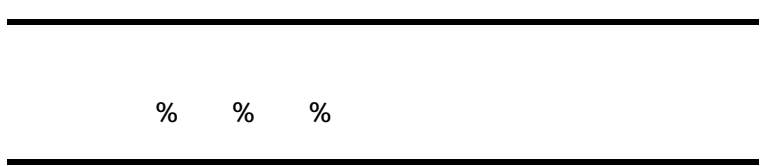

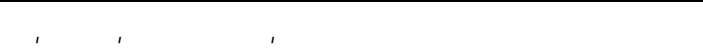

$\cdot, \varepsilon-\wedge \quad 10 \mathrm{rV}$

$\therefore, \varepsilon-\quad \Lambda \quad \mu\urcorner \quad 07$

*., ${ }^{\mu} \varepsilon \Lambda-\mu \quad r V, 079,0$

$* \cdot r \cdot \mu-\quad \mu \quad$ IV, 0 V१,

$., 11 \mu, 0 \quad r q 7,0$

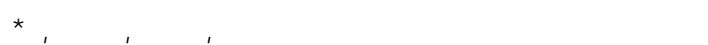

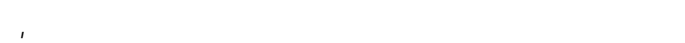

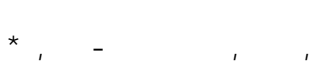

.

$\begin{array}{llll}\cdot, & r\end{array}$

*., IVI rו,0 ।. 14,0

, ו ו

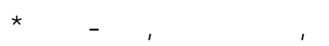

*., ११ $\mu \varepsilon, 0 \quad 17 \varepsilon 9,0$

*., rEV- $17 \mu \varepsilon, 0$ ह१,0

.r.- - $\quad$ - $\varepsilon, 0 \wedge 0,0$

*.,IVA- $\quad \mu \quad \varepsilon r, 0 \quad 0 \varepsilon, 0$

*.,r.0 r.,0 $1 \wedge \quad 71,0$

.V.- $r ו, 0$ r $r$ E $\varepsilon 7,0$

., $0 \quad \mu \mathrm{V}, \mathrm{O} \quad \mathrm{OV}, \mathrm{O}$

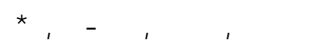

*., rIr rV,O 19,0 Or

*.,rV7- $\mu q, 0$ нr,0 rV

$\cdot, \varepsilon-\quad$ - 10,0 $\wedge \varepsilon, 0$

$\cdot, 1 \cdot-\quad 10 \quad \mu \varepsilon, 0 \quad 0 \cdot 0$

*IOH.- $\wedge \varepsilon \varepsilon, 0 \varepsilon V, 0$

., $1 \mu-\varepsilon, 0 \quad \mu \varepsilon 71,0$

$\cdot \wedge$ ।. 10,0 VE,0

$\cdot r-r 9,0$ rा 09,0

IT 17,0 IV 77,0

$* ., 17 V-r \varepsilon, 0 \quad 1 \wedge, 0$ OV

.). - "ו,0 17 or,0

*.,Irr- ro,o IV,0 ov
جطط 9: توزيع أفراد عينة الدرلسة مسب الوزن

\begin{tabular}{|c|c|c|c|c|}
\hline \multicolumn{2}{|c|}{ كالل العينة } & \multirow{2}{*}{$\begin{array}{c}\text { المداوسلة } \\
\%\end{array}$} & \multirow{2}{*}{$\begin{array}{c}\text { المكومية } \\
\text { المداوبة }\end{array}$} & \multirow{2}{*}{ وزن العينة } \\
\hline$\%$ & التكرار & & & \\
\hline rV & VE & rV & rV & a · - - سكجم \\
\hline 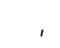 & س & $\mu$. & سץ & من اس - - عككج \\
\hline 11,0 & "r & 9 & $1 \varepsilon$ & من اع - - مكجم \\
\hline$r, 0$ & 0 & $\varepsilon$ & 1 & لثر aن · مكجه \\
\hline IV,0 & ro & $r$. & 10 & لم ينكر \\
\hline $1 \cdots$ & r.. & $1 \cdots$ & $1 \ldots$ & المجموع \\
\hline
\end{tabular}

جطل ا : توزع فراد عينة الدرلسة مسب اللطل

\begin{tabular}{|c|c|c|c|c|}
\hline \multicolumn{2}{|c|}{ كلل العينة } & 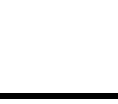 & المكومية & طلط المينة \\
\hline$\%$ & الكرار & $\%$ & $\%$ & \\
\hline$r, 0$ & v & $r$ & 0 & من . . 1 -10 السم \\
\hline$r 7$ & or & רץ & ד & من7 || || - ." السم \\
\hline$\mu \Lambda$ & v7 & ro & દા & اس ا -0 لهم \\
\hline$\Lambda, 0$ & IV & 9 & $\Lambda$ & من 7 السم فلكثر \\
\hline$r \varepsilon$ & $\varepsilon \Lambda$ & ru & $r$. & لم ينكر \\
\hline 1. & $r$. & 1. & 1. & المجموع \\
\hline
\end{tabular}

الهادل والفضل الغذائي: يوضح جدول (11) بعض الفضئ

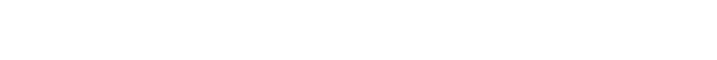

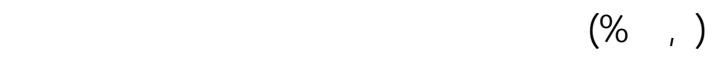

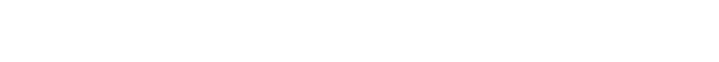

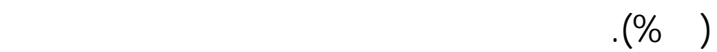

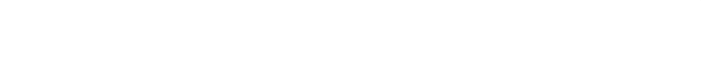
(\%79,0) الوجبة بدلا من وجبة الإفار. كما يتضح من من الجدول أن

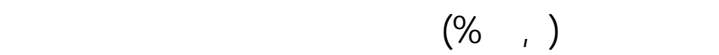

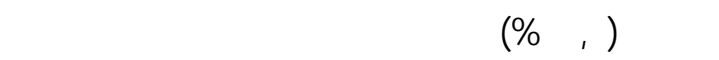

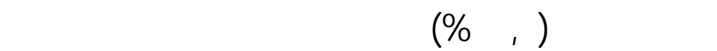

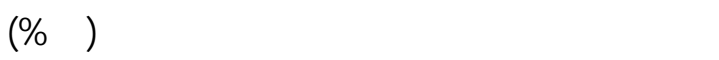

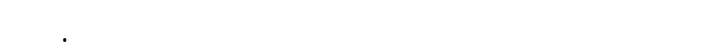

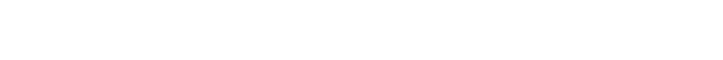
التغذوية وجود ارتبطل ذي دلالة معنوية بين المستوى التعليهي

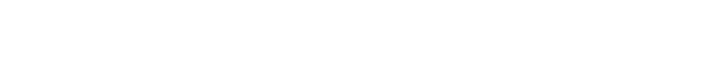
الحرص على تناول وجبة الغداء، في حين أن الارتبطل الدئل الدال

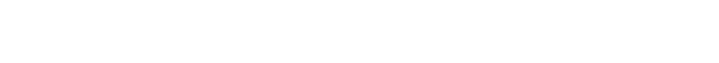


والبيتزا (77,0\%)شطائر البيض (17\%) واليف جرجر

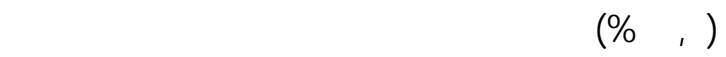

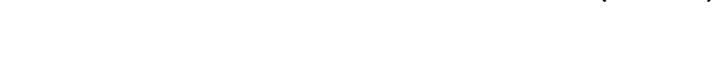
نصف العينة قفضلشرب المضائ (\%ov) أومضافا إليه

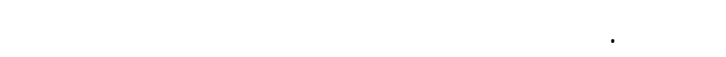

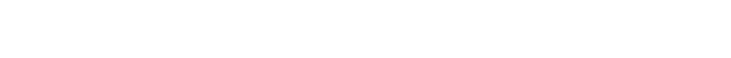

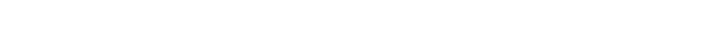
الطازج أوالمعلب أو الحليب المدعم.

\section{المحور الرليع للاستبلنة :}

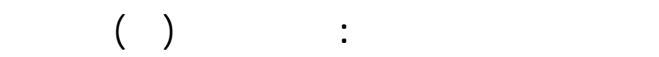

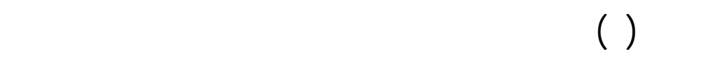

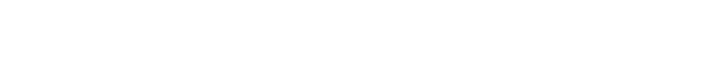

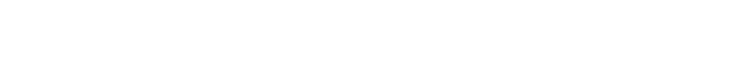

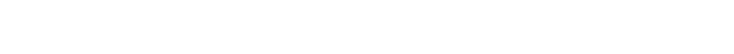

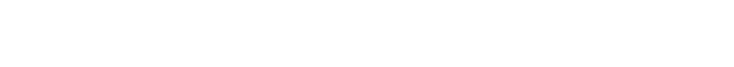
التغذوي والصهي لهُ.

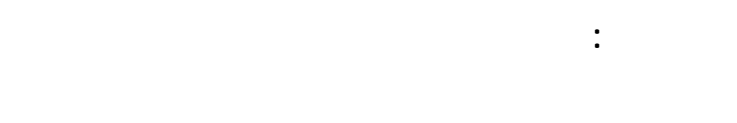

\begin{tabular}{|c|c|c|c|c|c|}
\hline الارتبلالمع النعتيمي & $\begin{array}{c}\text { y } \\
\text { \% } \\
\text { \% }\end{array}$ & $\begin{array}{c}\text { لاوائق } \\
\%\end{array}$ & $\begin{array}{c}\text { أولقق } \\
\%\end{array}$ & العبارل & م \\
\hline$\cdot, \cdot$ & 11 & 11,0 & $\mathrm{VV}, 0$ & والعضور والدجاج مهملن للنمو & 1 \\
\hline$* ., 109-$ & IV & 79,0 & $1 \mu, 0$ & الظليب والمأجنان. غير مهمين لنمو & $r$ \\
\hline$\cdot, 1 \cdot-$ & IV, 0 & 0 & $\mathrm{VV}, 0$ & الأمراضر والفولكه قفي الجم من & $\mu$ \\
\hline$\cdot, \cdot 9-$ & 7,0 & $\mu$ & $9 \cdot, 0$ & بالصحة. & $\varepsilon$ \\
\hline$\cdot, \cdot \Lambda-$ & 7,0 & $\Lambda \mu, 0$ & 1 . & الطظروبك الغازية لا تؤثر على & 0 \\
\hline$* \cdot, 19 \mu-$ & $r 0,0$ & $r r, 0$ & or & البطلس المقلية تسبب للسمنة. & 7 \\
\hline$\cdot, \cdot \Lambda-$ & н7 & $\varepsilon \Lambda, 0$ & 10,0 & 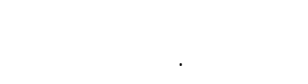 & $\mathrm{v}$ \\
\hline *, * + + + & r & $1 \cdot 0$ & 77,0 & الإكتارمن للسكر والحلويت & $\Lambda$ \\
\hline$\cdot, \cdot 9-$ & r & זس & ro & الإمسك. & 9 \\
\hline *., rq7 - & 9,0 & $0 \varepsilon, 0$ & нq & بالشطم. & 1 . \\
\hline *., гจ7+ & 19 & $\mathrm{~V}, 0$ & $V^{\mu}, 0$ & يومتاج. إلى كوبين من الحليب & 11 \\
\hline$\cdot, \cdot 1-$ & $1 \varepsilon$ & $r \varepsilon$ & זר & 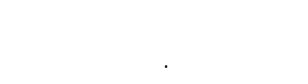 & ir \\
\hline$\cdot, \cdot \Lambda$ & $\mu$. & $1 \cdot, 0$ & 09,0 & الأسمك مهمة للصحة. & I \\
\hline$\cdot, \cdot 7-$ & 17,0 & $v \cdot, 0$ & $1 \mu$ & للمجعة الششه غير ضرورية & IE \\
\hline$\cdot, \cdot 7$ & 7,0 & 17 & $V V, 0$ & بالكسل الملم التلفاز يشعرني & 10 \\
\hline
\end{tabular}

*رل إحصائيا عند مستوى معنوية عند الل من 0 ×.,
وكما هو معلو فِلن المجتمع السعودي فيضل تتناول الأرز، إلا أن وجود العلاقة الارتبطية العكسية الدالة

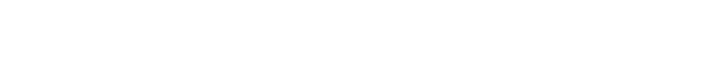

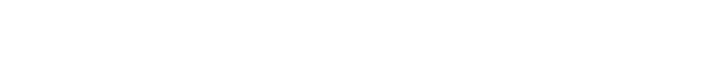

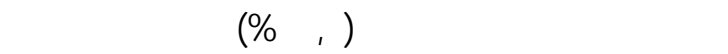

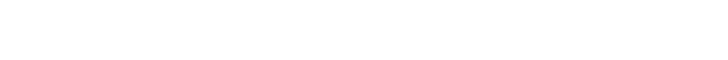

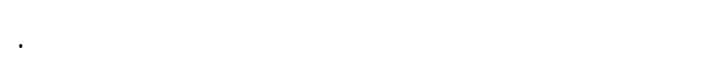

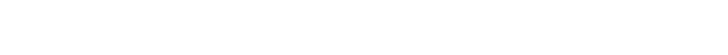

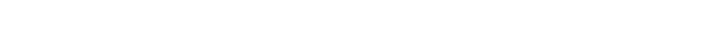
الإحصائي أن هنك علاقة ارتبطليه موجبة دالة إحصائيا بين

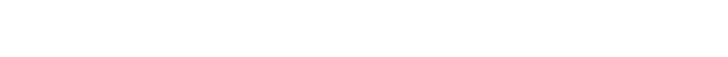

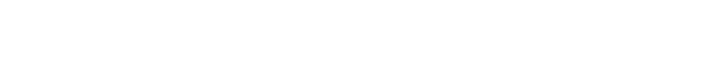

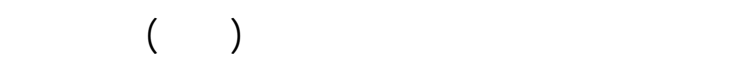

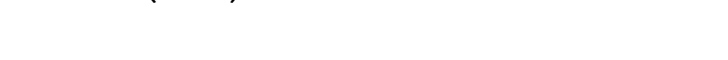

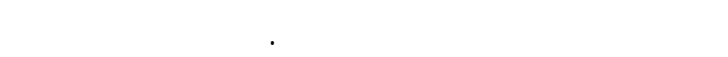

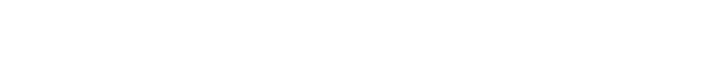

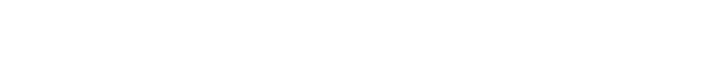

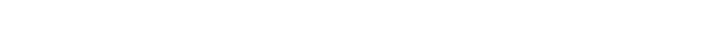
أن عينة البحث تتجه إلى الإفرطا في تناول الألعمة العالية العالية

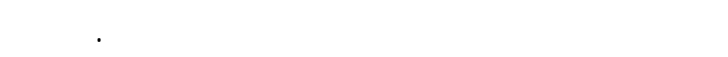

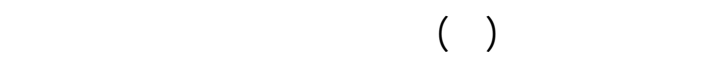

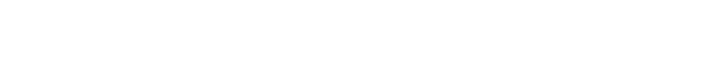

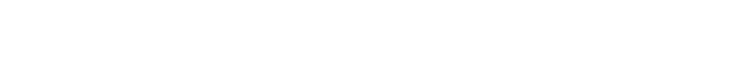

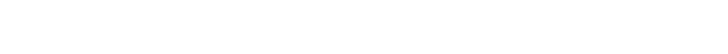

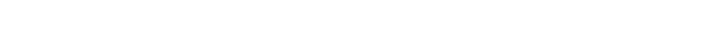

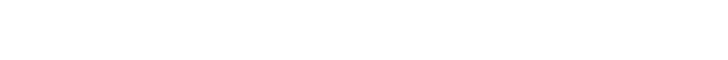

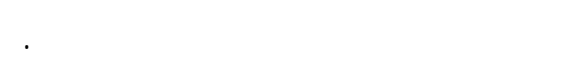

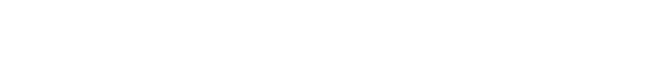

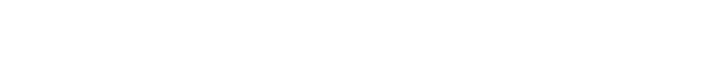

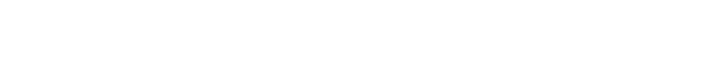

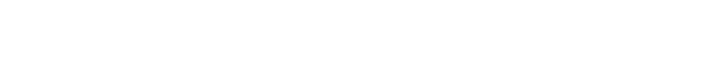

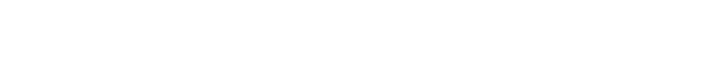

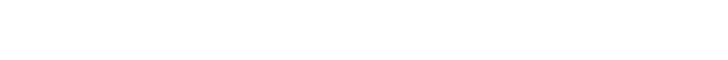

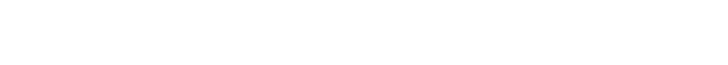

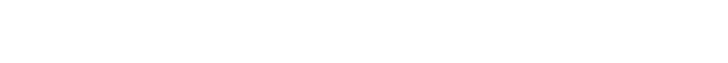
الحيد.وتبين من الجدول ارتفاع نسبة الفضيل للفولكه

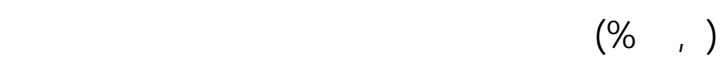

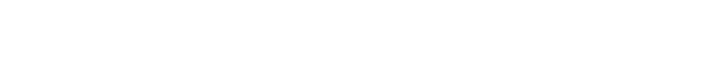

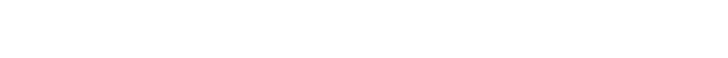

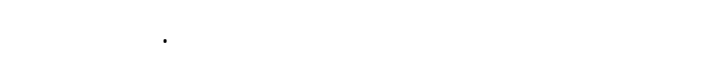

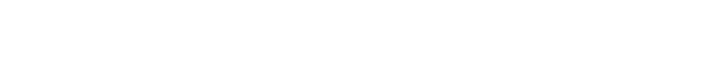
إحصائيا بين المستوى التعليمي للعينة وقفضيل التيل طبق

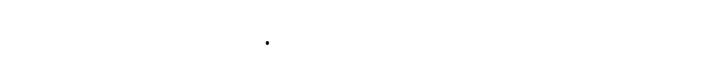

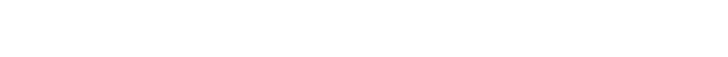

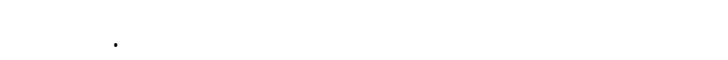

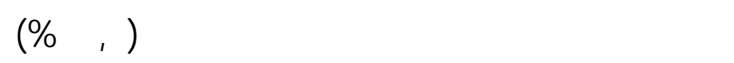




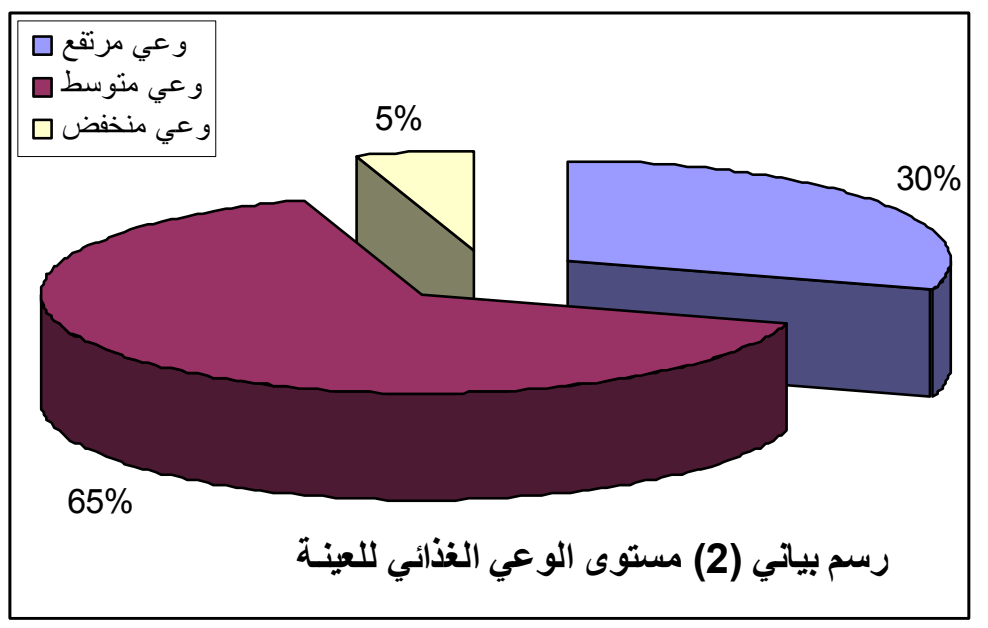

\begin{tabular}{|c|c|c|c|c|c|}
\hline$\cdot, \cdot 7$ & vo,o & 10,0 & 9 & بسكويت بالقثة & $\Lambda$ \\
\hline$\cdot, \cdot 7$ & $\varepsilon \Lambda$ & ـ & IV, 0 & بسكويت بالتمر & 9 \\
\hline$* \cdot$, rEา- & $\varepsilon, 0$ & દા & $O \varepsilon, 0$ & طولطس مقلية مع الكلثب & 1. \\
\hline$\cdot, \cdot \varepsilon$ & V & r & 71 & شرلئح جطلس مقلية في & 11 \\
\hline *., & ז" & $\varepsilon\rceil$ & זr & الأكيلئح جطع الظل مقلية في & ir \\
\hline$\cdot, \cdot 1$ & $\mu \wedge, 0$ & ri & $\varepsilon \cdot, 0$ & الأكيلئح مع الكلتشب مقلية في & $1 \mu$ \\
\hline$\cdot, \cdot \mathrm{V}-$ & rE & r & $\varepsilon \varepsilon$ & الشريلئح بطلفلس مقلية في & $1 \varepsilon$ \\
\hline *., , ८१- & r & ro,o & or,o & الذرة المفوشة & 10 \\
\hline *, พ^१- & 11,0 & $r r, 0$ & 77 & أصلع البوبو & 17 \\
\hline *, ${ }^{*}, \boldsymbol{\varepsilon}{ }^{\mu-}$ & IV & $\mu \cdot 0$ & or,o & ليسكريم عادي & IV \\
\hline$\cdot, 1$. & r & ir & 77 & $\begin{array}{r}\text { ليس كريم بالحليب } \\
\text { والشيكولانة }\end{array}$ & 11 \\
\hline$* \cdot, 1 \wedge \mathrm{V}+$ & $\varepsilon$. & - & 7. & ليس كريمساندويش & 19 \\
\hline r & v & 1,0 & ११,0 & عصيرطازج & $r$. \\
\hline$\cdot, \cdot 1-$ & $v$ & rV & 77 & عصيرمعلب & rI \\
\hline$\cdot, \cdot 0-$ & - & IV, 0 & $\Lambda r, 0$ & فولهمطازجة & r \\
\hline$r \cdot \mathrm{V}$ & v & $1 \%, 0$ & v१,0 & الكيك & $\mu$ \\
\hline$\cdot, \cdot \mathrm{V}$ & - & سו,0 & \urcorner$\wedge, 0$ & الحلويت & re \\
\hline$\cdot, \cdot 0$ & $\varepsilon \Lambda$ & 0,0 & $\varepsilon 7,0$ & مشروبكت غازية & ro \\
\hline$* \cdot, 17 \Lambda-$ & $V, 0$ & 17,0 & v7 & ساندويشن بالجن & r \\
\hline$\cdot, r-$ & 11,0 & $r^{\mu}, 0$ & 70 & ساندويش بالبيض & rV \\
\hline$\cdot, r$. & $r \mu, O$ & 17,0 & $7 \cdot$ & كرولسلن & rA \\
\hline
\end{tabular}

* دال إحصائيا عند مستوى معنوية عند الل من م. , .

\section{ثلنياً - الأصنال المدعمة بالفرع العسلي}

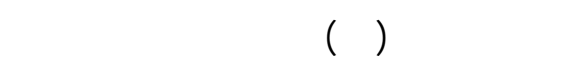

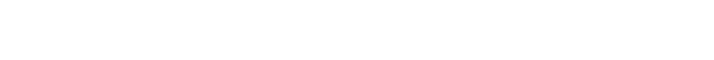
بالقرع العسلي،وعلى الرغم من وجود تالك الاختلافت في المان

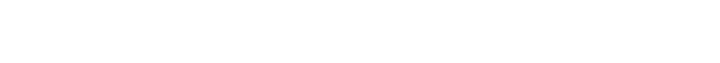
الأصنف المختارة على ققدير علم ممتاز.

\section{المحور الخلمسمن الإستبلة:}

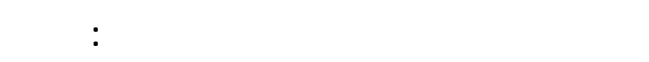

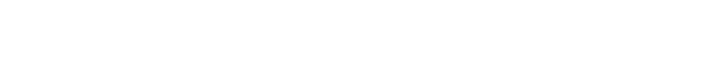

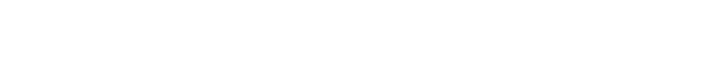

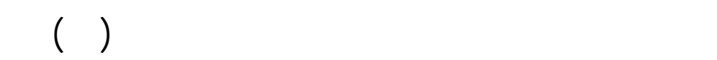

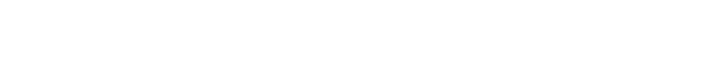

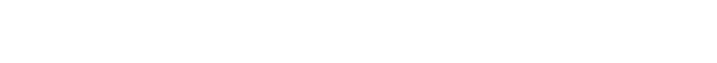

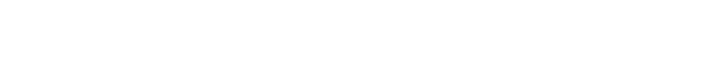

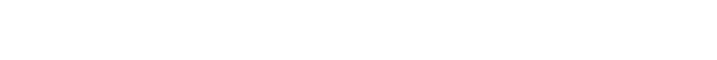

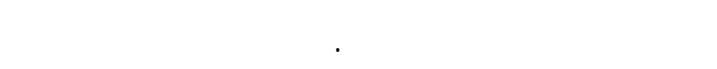

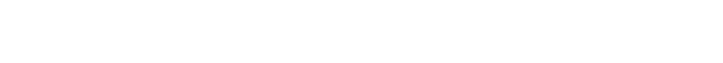

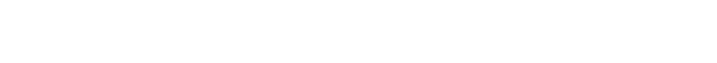

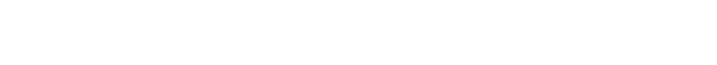

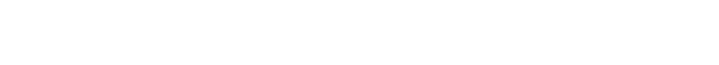

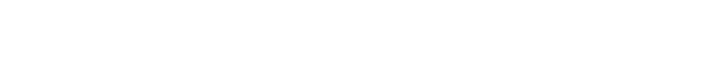

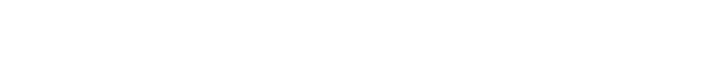
مؤثرا عن تأثير المعرفة والوعي التغذوي والتغيير في العادات على نوعية الطٔلعة المفضلة لناك الفئة العمرية.

جلط با: الملفة بين المستوى النطلي اللعينة ونوعية الألعمة الخفية المستهلكة بين الوجبلت

\begin{tabular}{|c|c|c|c|c|c|}
\hline الارتبطلمع العبليم & $\begin{array}{l}\boldsymbol{y} \\
\%\end{array}$ & $\begin{array}{c}\text { أحيلنا } \\
\%\end{array}$ & \% & الألمعة الغفيفة & م \\
\hline$\because \cdot$ & 07 & 10 & rq & الحليب المسالل الأبيض & 1 \\
\hline$\cdot, \cdot \mathrm{V}-$ & $1 \mu$ & ع & or & الحليب السالل بالثيكولاتة & $r$ \\
\hline$* .$, । १९- & " & r & 10 & الحليب المالل بالفراولة & $\mu$ \\
\hline$\cdot, 1 \cdot-$ & 09 & rl & $r \cdot$ & اللبن الزبادي بالفراوله & $\varepsilon$ \\
\hline$*$ *, гq१- & 9,0 & rq & 71,0 & كريمة كرامل & 0 \\
\hline$\cdot, I r-$ & $1 \wedge, 0$ & 19,0 & 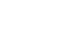 & فشار بالملح & 7 \\
\hline$* \cdot, \mid \mathrm{VI}-$ & ro & $\mu \mathrm{V}, 0$ & $r V, 0$ & بسكويت مالح & $\mathrm{v}$ \\
\hline
\end{tabular}


جدط عا: المتوط الهسلب ولانحرف المعياري لالمفل الهسية والقل العلم للأصنه المختارة قل وصد إضلفة الفرع العسل.

\begin{tabular}{|c|c|c|c|c|c|c|c|c|c|c|}
\hline \multicolumn{2}{|c|}{ القل العلم } & \multicolumn{2}{|c|}{ الفوله } & \multicolumn{2}{|c|}{ الرائحة } & \multicolumn{2}{|c|}{ اللم } & \multicolumn{2}{|c|}{ اللهن } & \multirow{2}{*}{ الصاف } \\
\hline ب & ق & ب & ق & ب & ق & ب & ق & ** & ق & \\
\hline$\Lambda, 0$ & $\Lambda, 77$ & $\Lambda, \Lambda \mu$ & 9,17 & $\Lambda, \Lambda \mu^{\mu}$ & q,ro & $\Lambda, \mu$ & $\Lambda, 77$ & q,ro & 9,77 & الدونلت \\
\hline 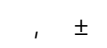 & $1,77 \pm$ & $\cdot, \Lambda \mu \pm$ & $1,19 \pm$ & $\cdot, \Lambda \mu \pm$ & $\cdot, \mathrm{VO} \pm$ & $1, \mu \mathrm{V} \vee \pm$ & ।,દ૧ & $\cdot, 97 \pm$ & ·, દ૧土 & "التحمير" \\
\hline 9,0 . & 9,0 . & 9,77 & $9,0 \wedge$ & 9,0 . & १,ह। & $9, \mu \mu$ & 9,0 . & $9,0 \wedge$ & 9,0 . & الكعك \\
\hline$\cdot, 7 V \pm$ & $\cdot, \mathrm{V} \pm$ & $\cdot, 70 \pm$ & $\cdot, \mathrm{V} \pm$ & $\cdot, 7 V \pm$ & $\cdot, \mathrm{V} \pm$ & $\cdot, \mathrm{VV} \pm$ & $\cdot, \mathrm{\vee} \pm$ & $\cdot, 77 \pm$ & $\cdot, \mathrm{\vee} \pm$ & "الفرن" \\
\hline ૧,દ। & 9,17 & Q, YO & $\Lambda, 91$ & ૧,દ) & Q, & 9,17 & १, . & $9,0 \ldots$ & ૧,દ। & حلوى الكورن \\
\hline$\cdot$, ७१ะ & $\cdot, \wedge \mu \pm$ & $\cdot, \Lambda 7 \pm$ & $1, \cdot 7 \pm$ & ·, マ१ะ & $\cdot, 70 \pm$ & $1, \cdot r \pm$ & $\cdot, 90 \pm$ & $\cdot, 7 V \pm$ & $\cdot, 77 \pm$ & فليكس \\
\hline 9,0 . & س & १, ro & $\Lambda, 91$ & 9,0 . & 9,17 & १, & $9, \cdot \wedge$ & 9,0 . & १, & البيتزا \\
\hline$\cdot, 7 V \pm$ & $\cdot, \mathrm{VV} \pm$ & $1,1 \mu \pm$ & $1, \wedge \pm$ & $\cdot, \vee १ \pm$ & $\cdot, \Lambda^{\mu} \pm$ & $\cdot, \mathrm{VV} \pm$ & $\cdot, 9 \cdot \pm$ & $\cdot, \mathrm{V} \pm$ & $\cdot, 70 \pm$ & "الفرن" \\
\hline $9, \cdots$ & $१, \cdot \wedge$ & $\Lambda, \Lambda \mu$ & १, ${ }^{\mu} \mu$ & १, ro & 9,17 & $\Lambda, 9)$ & $9, \cdot \wedge$ & $9, \cdot 1$ & 9,17 & البسبوسة \\
\hline $1, \cdot \varepsilon \pm$ & $\cdot, 9 \cdot \pm$ & $1,19 \pm$ & $\cdot, \Lambda \Lambda \pm$ & $1,0 \pm$ & $\cdot, 9^{\mu} \pm$ & $1,17 \pm$ & $\cdot, १ १ \pm$ & $\cdot, १ १ \pm$ & $\cdot, 9 \mu \pm$ & "الفرن" \\
\hline - - - - & १,१. & $-\ldots$ & १,१. & $-\ldots$ & १,१. & --- & $१, \wedge \cdot$ & - - - - & $৭, \wedge$. & العساء \\
\hline - - - - & $\cdot, \mu l \pm$ & - . - - & $\left.\cdot{ }^{\mu}\right) \pm$ & - - - - & $\cdot$, & - . - - & $\cdot, \varepsilon r \pm$ & - . - - & . $\varepsilon r \pm$ & "للسلق" \\
\hline
\end{tabular}

(الإبل ) IIV =)

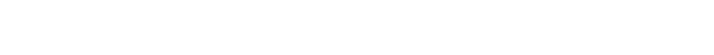

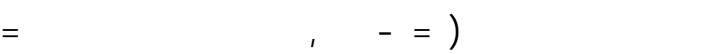
ا · , · بين المستوى التعليمي للأم ومدى تناول وجبة العشاء

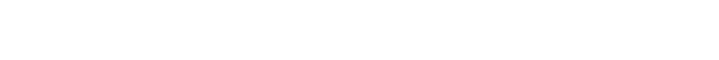

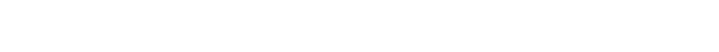
إلى لستبدل وجبة العشاء بوجبة من البطلس المقلية المبلية التئي تعي إعسلساً بلالثع.

وتعد وجبة الإفطارمن الوجبلت الرئيسية المهمة من

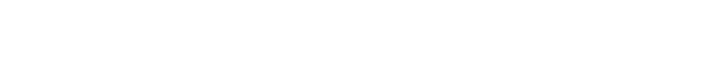
تناولها للشخص مما يؤثر على ششطله وتحمله للعطل، ويزيد

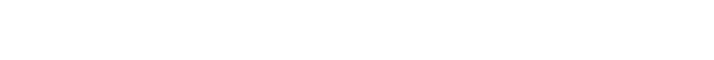

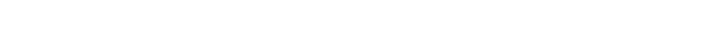

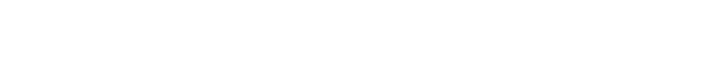
وعاة ما يصب الطٔفل النين لا يتناولون تلك الوجبة

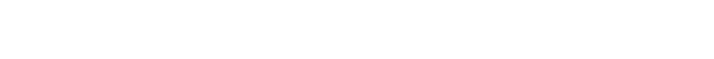
الدرلسي وضف الفاعل الذهني وزيادة الإجهاد الققلي

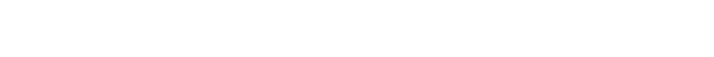

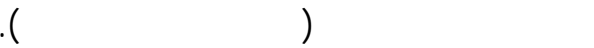
الفرض الثاني: هنك ارتبط بين مستوى تعليم كل من الأبوين ونوعية الألعمة المفضلة لعينة البهث: ثبت صحة هذا الفرض حيث ألثت التحليل الإحصائي بلستخدلم معال الارتبط أن هنك علاقة ارتبطيهسواء لخلنت

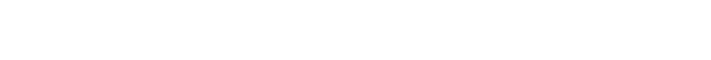

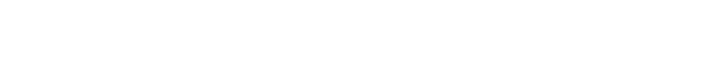
ارتبطيهسالبة دالة إحصائيا بين تعليم الأم وأبل عينة البهن
التأكدمن صحة الفروض الهرض الألط: هنك علاقة بين المستوى التعليهي للأبون والممارسك الغذلئية لعينة البحث: ثبت صحة هذا الفرض حيث أظلهر لختبار كاي

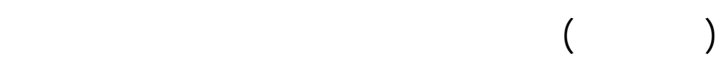
علاقة ارتبطيه دالة إحصائيا بين مستوى الحتبلئ لتعليم الأبوين والممارست الغذائية لعينة البحث.

جطر (10): الملفة بين طستوى تمكليم الأبون وصض العالت الغذائية للعينة البهث

\begin{tabular}{|c|c|c|c|c|c|}
\hline \multicolumn{2}{|c|}{ مستوى المعنوبة } & \multicolumn{2}{|c|}{ قيمةكاr } & \multirow{2}{*}{ الغذائية لعينة البهارثل } & \multirow[b]{2}{*}{ م } \\
\hline نمليم & لمعلم & تلعلم & لالم & & \\
\hline$\cdot, \cdots$ & $\cdot$, & q. & $V I, \Lambda r$ & بالمنزل يتناول وجبة الإفار & 1 \\
\hline$\cdot, \cdots$ & $\cdot, \cdots$ & $r \varepsilon, १\rceil$ & $r \wedge, 79$ & بالمد تتناول وجبة خفيفة & $r$ \\
\hline$\cdot, 17$ & $\cdot, \cdot 1$ & $\varepsilon, \varepsilon \Lambda$ & $\backslash \Lambda, V^{\mu}$ & بالمزل تتناول وجبة الغداء & $\mu$ \\
\hline$\cdot, \mu$ & $\cdot, \cdot \wedge$ & $1 \mu, \Lambda r$ & $r \cdot, 07$ & هل تلتناول وجبة & $\varepsilon$ \\
\hline$\cdot, \cdot r$ & $\cdot, \cdots$ & $r$ r & $0 \cdot 07$ & والمقلية بتناول وجبة الطلطس & 0 \\
\hline
\end{tabular}

ويؤكد التحلبل الإحصائي لمعال الارتبط النه كلما

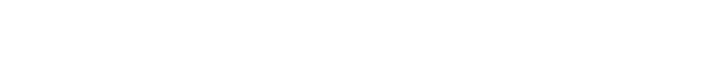

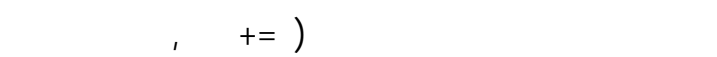

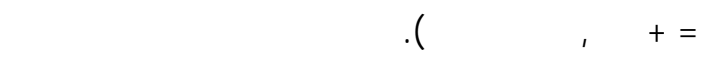




\begin{tabular}{|c|c|c|c|}
\hline$* ., \cdots$ & $1 \cdot, \cdot \mu 7$ & المشروبك الغازية مضرة بالصحة. & $\varepsilon$ \\
\hline$* ., \cdots \varepsilon$ & $\varepsilon, 700$ & المشروبك الغازية لا تؤثر على الظلم. & 0 \\
\hline$* ., \ldots \mu$ & $\varepsilon, \Lambda I V$ & الططلس المقلية تسبب اللمنة. & 7 \\
\hline 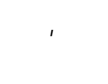 & ( & الصحة. الإثار من تناول الملح لا يؤثر عله & $\mathrm{V}$ \\
\hline$* \cdot, \cdot \cdot$ & $1 \cdot, \cdot 77$ & مرض الإكثار من المسكر والحلويت تسبب & $\wedge$ \\
\hline$* \cdot, \cdot$ & $7, \wedge 97$ & عدم تناول اللسطة يسب الإمسك. & 9 \\
\hline$* ., \cdot 9$ & $r, 1 \mu q$ & عدم ممارسة الرياضة تشعرني بالنشط. & 1 . \\
\hline$\cdot$ - $1 \cdot r$ & $r, \cdot 90$ & لحتاج إلى كوبين من الحليب يوميا. & 11 \\
\hline$* \cdot, \cdot 1$ & ґ,^દ૧ & بالصحة. الإثمن تناول البيض لا يضر & ir \\
\hline$* \cdot, \cdots \mathrm{V}$ & $\varepsilon, 170$ & الأسمك مهمة للصحة. & $1 \%$ \\
\hline$* ., \cdot$ & ir,oro & أشعة الثشس غير ضرورية للجهم. & $1 \varepsilon$ \\
\hline$* ., \cdots \mathrm{V}$ & $\varepsilon, r \cdot 1$ & الجلوس أملم التلفاز يشعرني بالكسل & 10 \\
\hline
\end{tabular}

جطل V I : الملافة بين المستوى التهيمي للأمهات وهستوى الوبمي الغنوي لمينة البحث

\begin{tabular}{|c|c|c|c|}
\hline | مستوى & قيمةف & العبارلت العلمية & م \\
\hline$* \cdot, \cdot r \wedge$ & $r, v V V$ & اللحوم والدجاج مهمان للنمو والعضلات & 1 \\
\hline$\cdot, .0 \varepsilon$ & $r, \mu \vee \mu$ & والألحنب والجبن غيرمهمين لنمو الظلم & r \\
\hline$\cdot$, rیI & 1, rVo & الخضر والفولكه نقي الجسم من الأمراض. & $\mu$ \\
\hline$* \cdot, \cdots$ & $৭, \wedge \mu)$ & المشروبكت الغازية مضرة بالصحة. & $\varepsilon$ \\
\hline$\cdot, 7 \varepsilon ।$ & אשר, · & المشروبكت الغازية لا تؤثر على الظلم. & 0 \\
\hline$*_{\cdot}, \cdots$ & $v, \cdots 9$ & البطلس المقلية تسبب للسمنة. & 7 \\
\hline$\cdot, \mathrm{rOO}$ & $1, \mathrm{r} \varepsilon \varepsilon$ & الصحة. الإكثار تناول الملح لايؤَر على & V \\
\hline$* \cdot, \cdots$ & $\mathrm{V}, 01 \mathrm{~V}$ & اللسكر. & $\Lambda$ \\
\hline$* \cdot, \cdot \cdot 1$ & $0, \cdot V_{1}$ & عدم تناول اللسطة يسبب الإمسك. & 9 \\
\hline$* \cdot, \cdot \cdot 1$ & אי & عدم ممالسة الرياضة تشعرني بالنشط. . & 1 . \\
\hline - & $1,1 \wedge \varepsilon$ & لحتاج إلى كوبين من الحليب يوميا. & 11 \\
\hline$* \cdot, \cdots$ & $0, r \varepsilon r$ & الإكثارمن تناول البيض لا يضر بالصحة. & ir \\
\hline$* ., \ldots$ & V, & الأسمك مهمة اللصحة. & Ir \\
\hline$\cdot$, Tro & $\cdot, 70 \varepsilon$ & ألشعة الشهس غير ضرورية للجم. & $1 \varepsilon$ \\
\hline$* ., \cdots$ & 10, ror & الجلوس أملم التلفاز يشعرني بالكسل & 10 \\
\hline
\end{tabular}

* دل لحصائيا عند مستوى معنوية الل من 0 . , . .

الفرض الرلع: أن هنك علاقة بين المستوى التعليمي

لأفراد للعينة والوعي التغذوي لديه:

ثبت صحة هذا الفرض حيث أظطهر التحليل الإحصائي لاختبار ANOVA وجود علاقة دالة إحصائيا

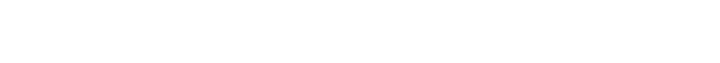

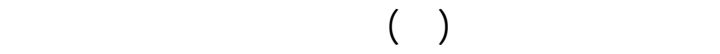

على تتاول البسكويت المالح (رAV-1,, عند مستوى

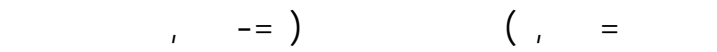

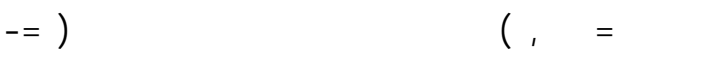

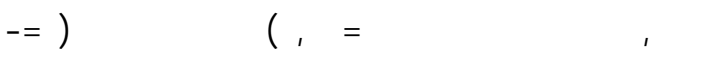

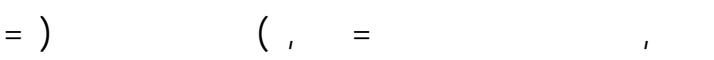

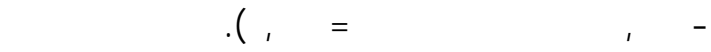
موجب دل إحصائيا مع عنتهاك الآيس كريم (العاني) الخالي

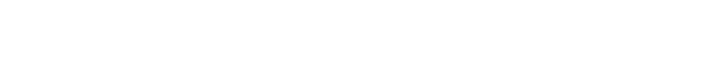
ونكهلت صناعية (ربr=r

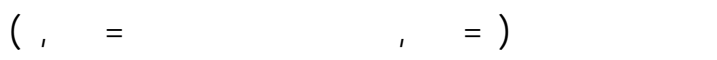

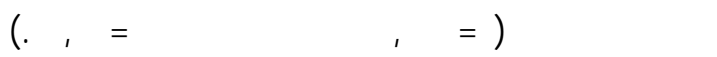
كما لتضح وجود علاقة ارتبطيهسالبة دالة إحصائيا بين تعليم

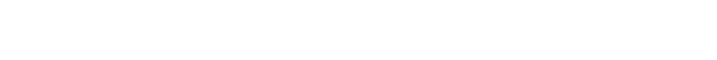

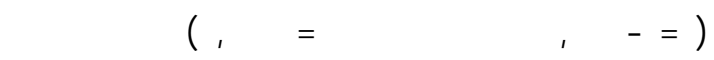
)

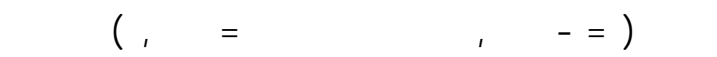
وجد أن هنك علاقة ارتبطيه موجبة دالة إحصائيا ين تعليم الأب ولستهلاك عينة البهث للحليب المدعم ب بالثيكولاتة

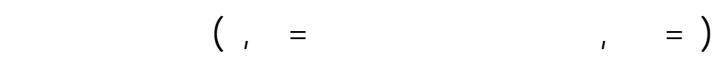

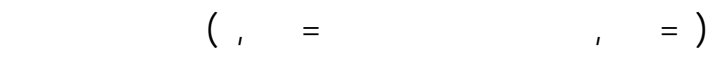

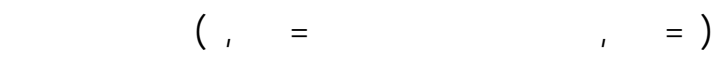

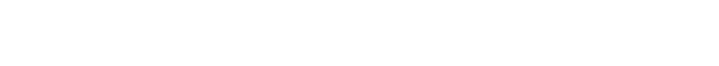
في طستهلاك العينة للألعمة المملحة وثرلئح البططس المقلئية والمشروبت الغازية والبططس المقلية والحلويت والفولهه والحليب المدعم. الفرض الثالث: هنك علاقة بين المستوى التعليهي لكلا الأبوين والوعي الغذائي لعينة البهث: لظٔهر التحللي الإحصائي بلجراء لختبار صحة هذا الفرض، حيث وجدت علاقة دالة إحصائيا بين المستوى التعليمي للأبونين والوعي التغذوي لعينة البهث

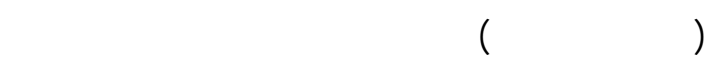
التعليمي للأبون كلما زاد المستوى المعرفي لأفراد العينة.

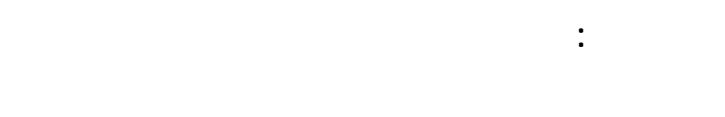

\begin{tabular}{|c|c|c|c|}
\hline المعنوبة & قيمةف & العبارت العامية & م \\
\hline$* \cdot, \cdots \wedge$ & $\varepsilon, \cdot 0 \wedge$ & اللحوم والدجاج مهمان للنمو والعضلات & 1 \\
\hline$* ., \cdots$ & $9,1^{\mu}$ & والأليب والجنن غيرمهمين لنمو الظله & $r$ \\
\hline$* ., \cdot 1 \mu$ & $\mathrm{r}, \mathrm{V} \cdot \mathrm{O}$ & الأمضراض. والفولكه قي الجمم من & $\mu$ \\
\hline
\end{tabular}


الكاروتين ثابتة لا تتنأثر بالأحماض والقلويت لجابا،

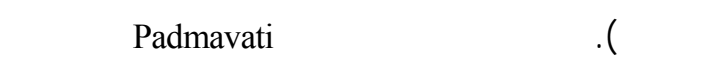

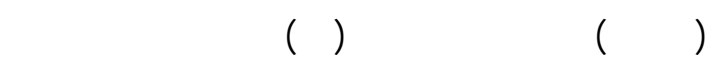

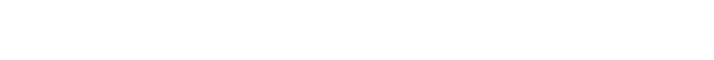

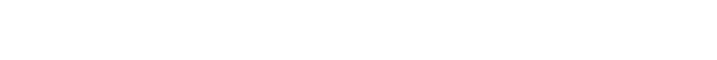

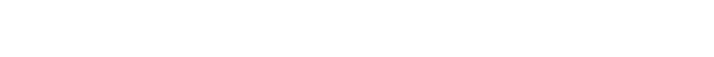
نسبة فقد عند لستخدلم التحمير العميق بالمقارنة بطريقة التثويح وكلتت الل فنبة فقد بلستخدلمطبقريقة الطهي بالبخار.

جلط 19: طلالة المرق الإحصئية المفل الهسية للأصنال المختارة قل وصد إلفلفة الفرع

العسلي

\begin{tabular}{|c|c|c|c|c|c|}
\hline \multicolumn{4}{|c|}{ المفلت الهسية } & \multirow{2}{*}{\multicolumn{2}{|c|}{ الأصنال }} \\
\hline الفولم & الرائحة & لالعم & اللهن & & \\
\hline $1, \varepsilon \Lambda$ & $r, 10$ & $1, \varepsilon \wedge$ & 1,7 . & "قيمةت" & الدونت \\
\hline س & $\cdot, \cdot 0$ & - 177 & - & "مستوى الدلالة" & \\
\hline $1, \cdots$ & $1, \cdots$ & $\cdot, \wedge \cdot$ & $\cdot, 07-$ & " قيمةت" & الكطك \\
\hline س山, & س & 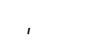 & $\cdot, 0 \wedge$ & ستوى الدلالة" & \\
\hline ·, १४- & $\cdot, 07-$ & ·,79- & ·, זq- & ل "قيمةت" & حلوى الك \\
\hline ד & $\cdot, 0 \Lambda$ & $\cdot 0$ & $\cdot, \mathrm{VV}$ & مستوى الدلالة" & \\
\hline I,ع^ - & $\mathrm{I}, \mathrm{V}-$ & $1,1 \varepsilon-$ & $\cdot, \Lambda \cdot-$ & "قيمة ت" & البيتزا \\
\hline$\cdot, 177$ & $\cdot$, & · & 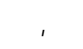 & مستوى الدلالة" & \\
\hline 1,ro & $\cdot, 071-$ & $\cdot, 07$ & ع ז, & "قيمة ت" & البسبوسة \\
\hline س & $\cdot, 0 \Lambda$ & $\cdot, 01$ & $\cdot, \Lambda$. & مستوى الدلالة" & \\
\hline
\end{tabular}

الفرض السلس: عمم وجود الختله في درجة القلل

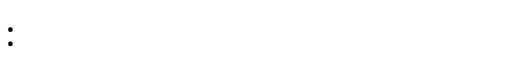
ثبت صحة هذا الفرض، حيث لم يظهر التحليل الإحصائي بلستعمل لختبار (ت) وجود فروق معنوية في

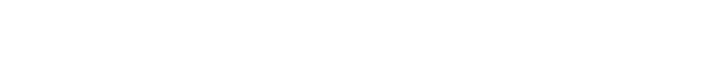

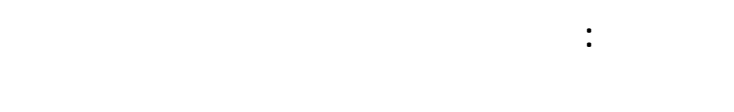

العسلي

\begin{tabular}{|c|c|c|c|}
\hline مستوى الدلالة & & قيمة (ت) & الأصناd \\
\hline غير دل لحصائيا & 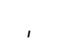 & $1, \cdots$ & الدونات \\
\hline غير دل لحصائيا & $1, \cdots$ & $\cdot, \cdots$ & 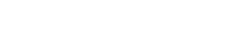 \\
\hline غير دل لحصائيا & $\cdot, r V$ & 1, 1 દ૧ - & حلوى الكورن فليكس \\
\hline غير دل لحصائيا & $\cdot, 0$ & $\cdot, 79-$ & البيتزا \\
\hline غير دال لحصائيا & $\cdot, \wedge \cdot$ & $\cdot, r \varepsilon$ & البسبوسة \\
\hline
\end{tabular}

العبارات، مما يؤكد إرقفاع المستوى المعرفي بارقفاع المستوى التعليمي للعينة.

جلط 11: يوضنح الملفة بين المستوى التليي للمينة ونستوى الوبمي التغنوي لهن

\begin{tabular}{|c|c|c|c|}
\hline | المعنوبة * & فيمة & العبارل & م \\
\hline$* \cdot, \cdot r$ & 0,0 & اللحوم والدجاج مهملن للنمو والعضلات & 1 \\
\hline$\cdot$ & 1,91 & والأليب والجبن غير مهمين لنمو الظلم & $r$ \\
\hline$\cdot, 11$ & $1, \pi$ & الخضر والفولكه قي الجسم من الأمراض. & $\mu$ \\
\hline$*_{.}, \cdots$ & $7, \varepsilon 0$ & المشروبك الغازية مضرة بالصحة. & $\varepsilon$ \\
\hline$* ., \cdot r$ & $\mu, I V$ & المشروبكت الغازية لا تؤثر على الظظلم. & 0 \\
\hline$* ., \cdots$ & $11,1 \mathrm{~V}$ & الطلطس المقلية تسبب اللسمنة. & 7 \\
\hline$\cdot, \mu \cdot$ & $1, r$ & الإكثار من تناول الملح لا يؤثر على الصحة. & $\mathrm{v}$ \\
\hline$* ., \cdots$ & ৩,१९ & اللسكر. من اللسكر والحلويت تسبب مرض & $\Lambda$ \\
\hline$*_{.}, \cdots$ & $11, \mathrm{rO}$ & عمم تناول اللسطة يسب الإمسك. & 9 \\
\hline$* \cdot, \cdot$ & $1 \mu, \wedge$ & عدم ممارسة الرياضة تشعرني بالنشط. & 1 . \\
\hline$*_{.}, \cdots$ & $7, \mathrm{~V} \cdot$ & لحتاج إلى كوبين من الحليب يوميا. & 11 \\
\hline$\cdot, \cdot 0$ & $r, 7$. & الإكثارمن تناول البيض لا يضر بالصحة . & Ir \\
\hline$* \cdot, \cdot r$ & $\varepsilon, \wedge 0$ & الأسمك مهمة للصحة. & r \\
\hline$* ., \cdot$. & $r, \Lambda \mu$ & لأشعة الشهمس غير ضرورية للجسم. & $1 \varepsilon$ \\
\hline$* \cdot, \cdot \cdot$ & 7,0 . & الجلوس أملم التلفاز يشعرني بالكسل & 10 \\
\hline
\end{tabular}

* دل إحصائيا عند مستوى معنوية الثل من 0 .,

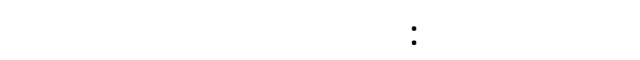

المفلت الهسية للأصناف المختارة قل وصد إلهنة

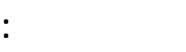

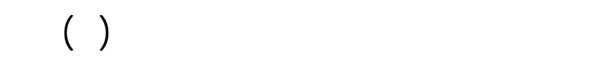

وجود فروق ذات دلالة إحصائية في الصفات الهسية

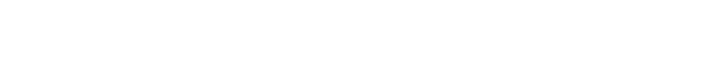

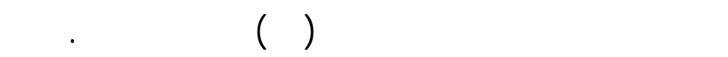

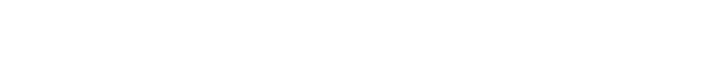
أثناء عملية الطهي إلى إحداث تغيرات في القيمة القيمة التغذوية

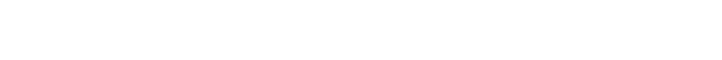
للمضغ والهضم والمستساغة وكذا حظظه من الفساد اللدريع

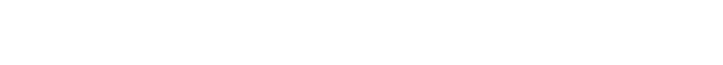
الإذزيملت التي تساعد على تدهور النكهة والقوله واللون

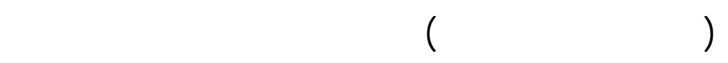
المختلة التي يمكن بها طهي الخضراوات ومنها طريقة اللسق،والتسبيك، والطهي في الفرن، والتحمير،وللسلق بالبخار

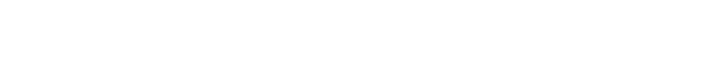

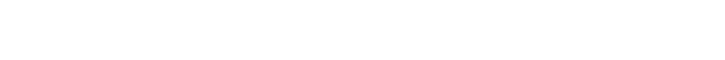

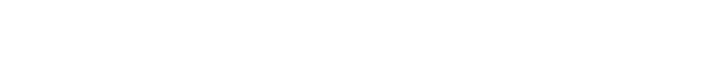




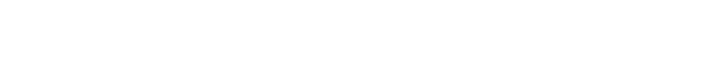
الحرص على وجود القدوة الهسنة كالوالين والمدرسين

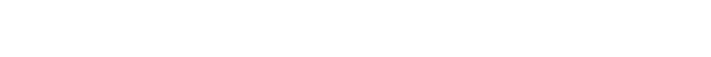
والتعليمك التي تتعلق بالاختيار الجيد للألعمة الصحية النياء

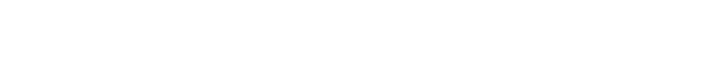

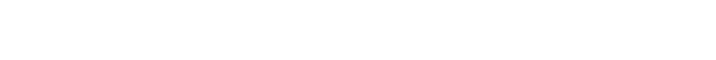
الغذاء كوسيلة للثوب أو العقلب.

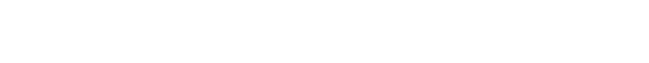
والككك والحلويت ووجود العلاقة الارتبطلية العكسية بين العنين

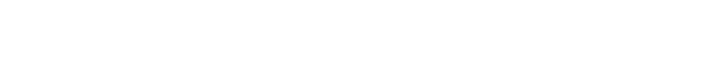

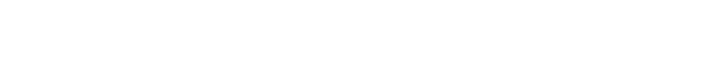

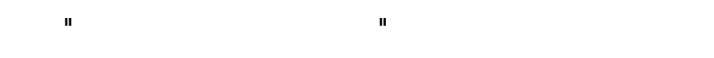
لظٔهرت نتائج القبل عدم وجود فروق ذات دلالة إحصائية

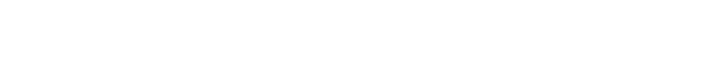

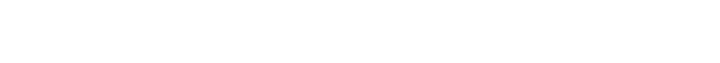

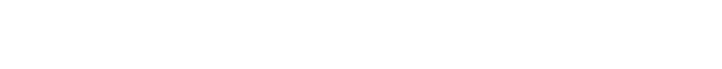

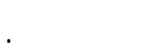

\section{التوصيات}

I - التلكيد على ضرورة توفير عبوات الحليب للسالل

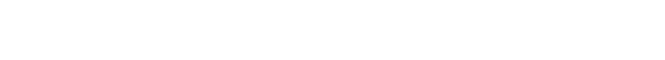

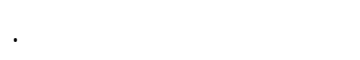

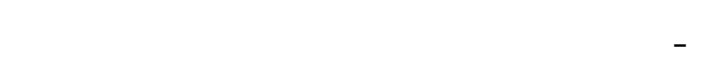
التي ترتفع بها نسبة الحموضة على صحة الأسنان . ب - عل برلمج توعية تغذوية بأهمية لمتهلاك الألعمة الني ينخل في تكوينها التمر لارتفاع قيمته التغذوية. ع - إن تدعيم بعض الأطعة المحبة إلى الطٔلفل كالكيك

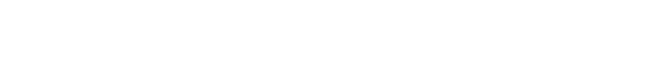
بصبغة البيتلكاروتين قد يقل من الآثار الناتجة من كثرة تناول الأطعمة الغنية بالدهون والنغفاض تقاض الناول الأطعمة الغنية بمضادات الأمسدة.

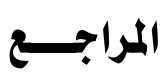

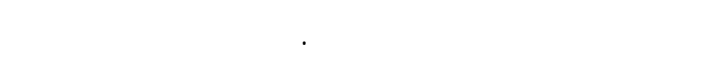
والنوعي لدى معلملت الإتصاد المززلي بمحافظة المالية الإسماعيلية. المجلة المصرية للاقتصاد المنزلي، العدد العاديا

$$
\text { .90: (1ع) }
$$

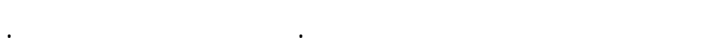
درلسة الحالة الغذائية في رياض الألفال بدولة قطار.

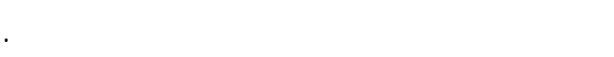

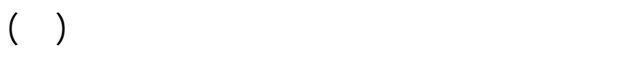
ص:

\section{مناقشة النتائج}

تؤثر معلوملت والتجاهلت وسلوكيت الوالدن مبلثرة على العادات الغذائية لالطلبة، فالوالدين هما اللذان يحددان

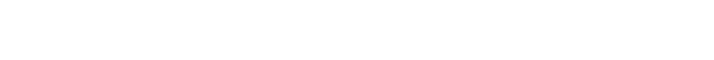

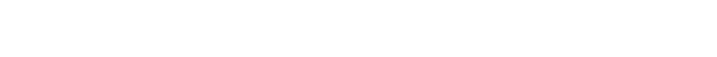

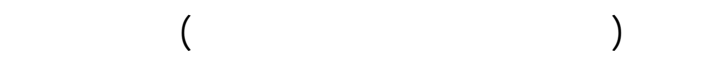

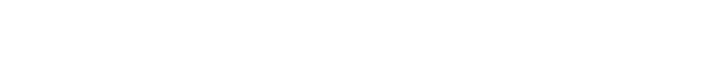
للأبوين وانعكس ذالك على السلوكيلت الغذائية لعينة الدرلسة (الفرضان الأول والثاني)، ولا يقل أهمية الهية دور المدرسة عن دور المذزل في تعليم الطفل للسلوك والعادات

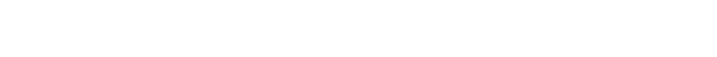
تعليم تلاميذ المداس علم التغنية من خلل مناهج التعليم

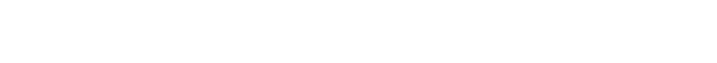

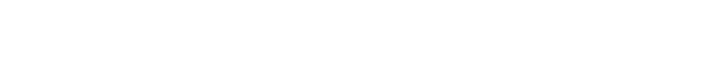
صحته وتعريفه بكيفية سد لحتيلجاته التغذوية بالبدائل

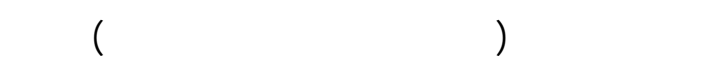

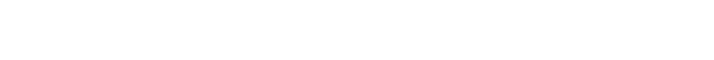

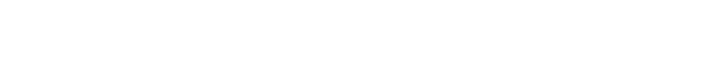
اللسلوكيت والعادات التغذوية الخطائة وخاصة من مع فندم العمر وارففاع المستوى التعليهي لدى أوراد العينة (جداول

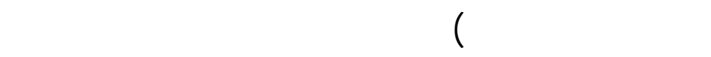

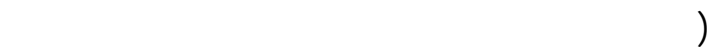

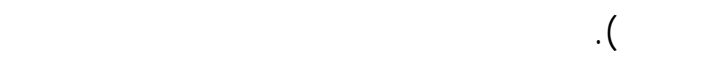

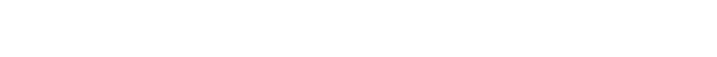
الدرلسة قارب السلوك التغذوي للعينة مع اللسلوك التغذوي

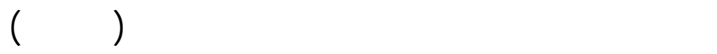

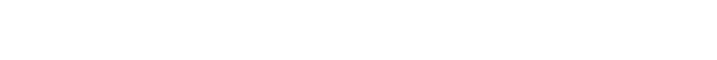

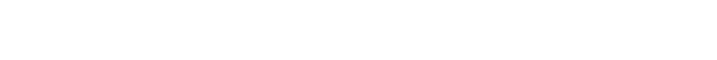

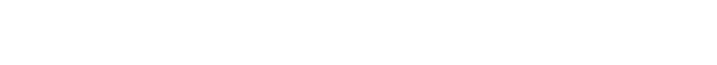
على حالتهم الصحية والتغذوية، وقد ظهر ذاركا فيلك جليا في

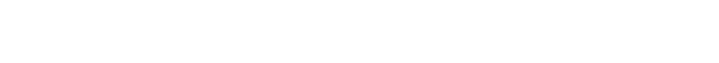

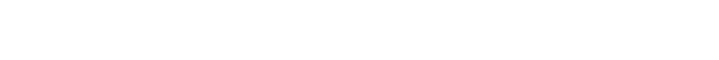

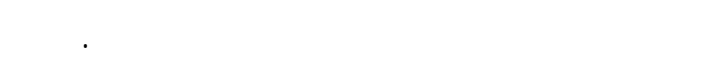

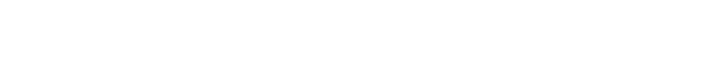
ثلث السكان، ويمرون في هذه المرحلة العنالة العمرية بتغيرات

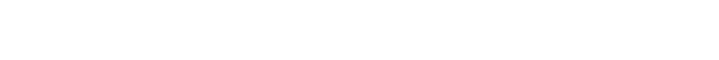

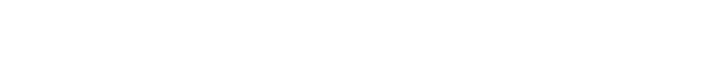

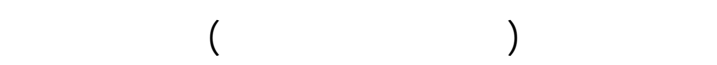

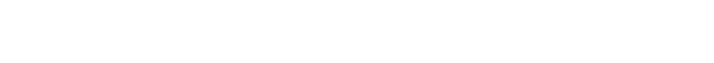

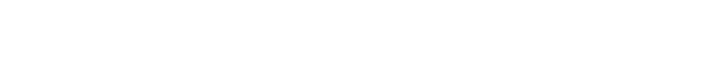
الدرلسة على تتناولها (جدول 11)، والإقلال جقدر الإمكان 
خلف آ، عبد العزيز وعبد الطفي، محمد ومحمد، محمد والثرقاوي، عبد العزيز وبدر، هاني 997 لم. لأسلسيك ولتنتاج الخضراوات، مكتبة المعارف الحيية، الإسكندرية.

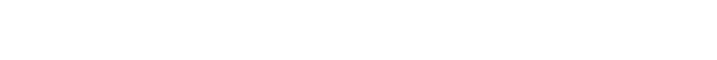

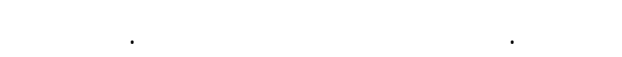
وتكنولوجيا الأغنية، كلية الزراعة، جلمعة الإسكندرية. بسالة كليت البنت سrاعاهـ.. العدد (ro) نقيم الحالة الغذائية لطالبلت المرحلة الابتدائية بمدينة الرياض، بسالة كتوره مقدمة من الطالبة نادية محمد النيجاني. سابا، نرجس حبيب إوالم. الطهي علم وفن. الطبعة الثالثة.

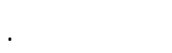

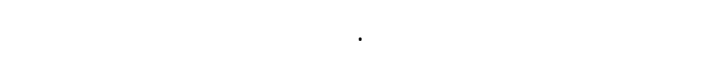
تشجبع الطأفل على شرراء وتناول الاغنية المسلية.

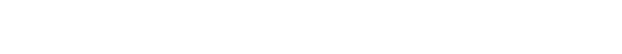

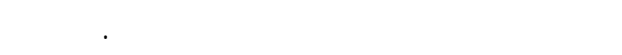
الإسكدرية للاقتصاد المنزلي، كلية الزراعة، جلمعة الإلمية

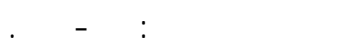

صبهي، كفلف هسين ع.مجم. التربية الغذائية والصحية. مجموعة النل العربية، الطبعة الأوله، القاهرة، ص: V. V.

عالم، عوطاف علي 11 اعاهـ.. التقف الصهي والغذائي.

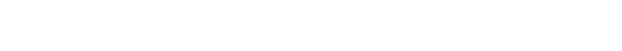

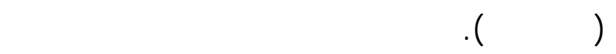

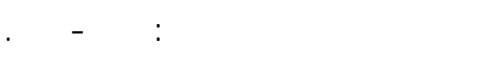

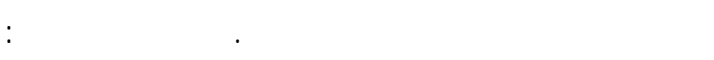
الظرية والطبق. مكتبة عين شهص، القاهرة ص:

$$
\text { r rAV-rาE }
$$

عبد الوهلب، منال جلل 999 ام. لأسس القافة الصحية. مكتبة

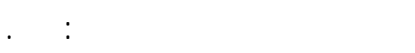

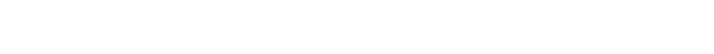

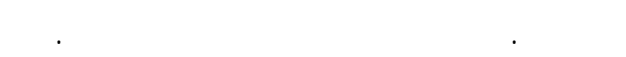

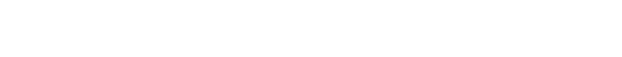

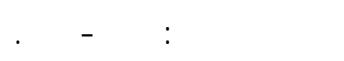

قمصانيطه والمدن، خالد r...م. مضادات الأكسة بين

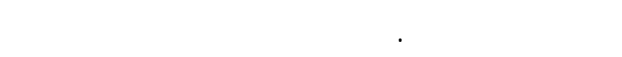

$$
\text { للسعودية بمصر. }
$$

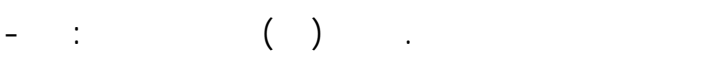

.rv

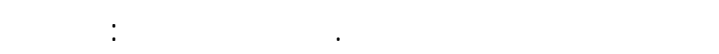

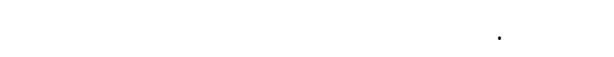

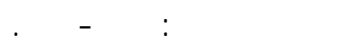

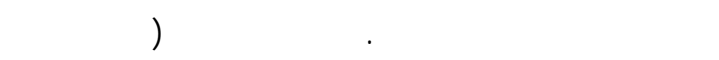

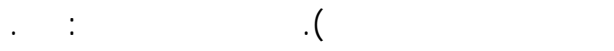

الركبان، محمد عثان ع ..-م. السلوكيت الغذائية والعولمل المؤثرة فيها لدى المراهن في مدينة الرياض .المجلة المدئ

العربية للغذاء والتغذية. اللسنة الخلمسة، العدد (II) ص: 07 - 07 .

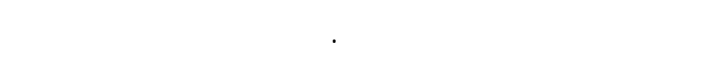

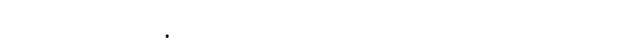
العمل حول إماج المفاهيم والمعلومات المتعلقة بالتغذية

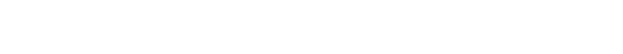
الخليجي. تقظيم جمعية التغنية العربية ومركز البحرية البحرين للدرلسلت والبحوث ومظمة الأمم المتحة اللتربية اللحبية والعلوم والقالفة - المكتب الإقليهي للدول العربية في الإنية

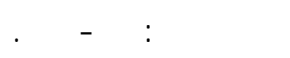

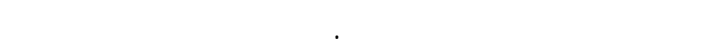
البنات في المملكة العربية للسعودية.وقائع ندوة التغذية المبلية

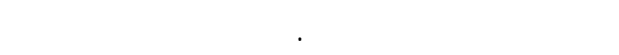
العربية للغذاء والتغنية (ع)، مركز البحرين للدرلسلت

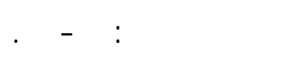

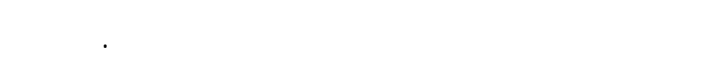

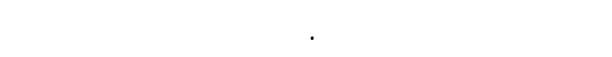

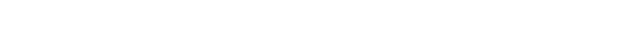
الإدارة العلمة للخدملت الطبية. المملكة العربية العالية

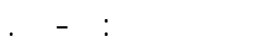

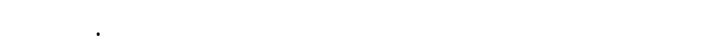

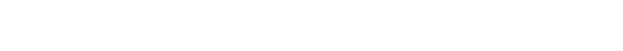

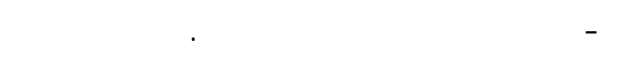

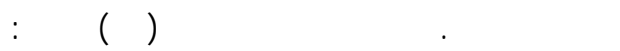
. $1 \cdot V-\Lambda 7$

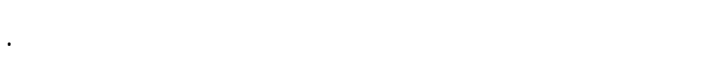
القفلة الصحية. الطبعة الأوله. دار للسلمسل. الكويت،

$$
\text { ص: }
$$

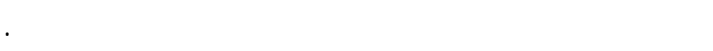

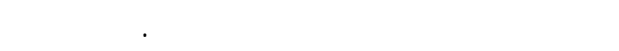

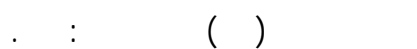

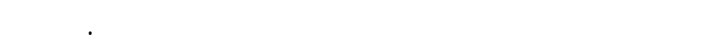
والتغنية في اللن المدبسي. جلة، المملكة العربية

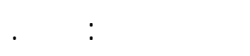

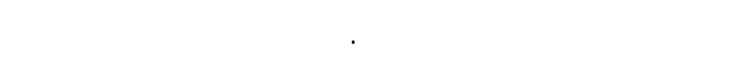

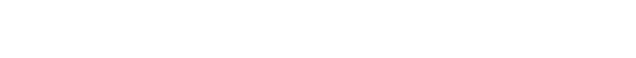
على القيمة الغذائية وققل المستهلك لبعض منتباتئه

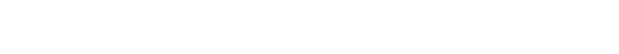
جمهورية مصر العربية. حمالي، علي صبحي 999 الم. الوعي الغذائي وصحة الإنسان. منشأة المعارف، الإسكندرية. 
Lamp, J. 1999. Health effects of vegetables and fruits: Assessing mechanisms of action in human experimental studies. Am. J. Clin. Nutr., 70 (supp1): 475S-490S.

Ojimelukwe, P. \& Ezeji, C. 1993. Effect of fermentation on the nutritional quality and functional properties of infant food formulations prepared from bambarra-groundnut, fluted-pumpkin and millet seeds. Plant Foods Hum.Nutr., 44: 26776.

Osman, M., Magbool, G. \& Kaul, K. 1993. Hegira Adaptation of the NCHS weight and height charts. Annals of Saudi Medicine, 13(2) :170-171.

Powles, J. \& Ness, A. 1997. Fruit and vegetables, and cardiovascular disease: A review. Lnt. J. Epidemiol. 26:1-13.

Padmavati, K, Udipi, S.A. \& Rao, M. 1993. Effect of different cooking methods on beta-carotene content of vegetables. J. Food Sci. Techno. Mysore 29(3): 137-140

Rodriguez, D. 1999. Latin American food sources of carotinds. Arch latinoam Nutr., 49 (3 supply 1) :74S-84S.

Steimetz, K.A \& Potter, J.D. 1996. Vegetables, fruits, cancer prevention: A review. J. Amer. Diabetic Association, 96 (10): 1039

Stevenson, J. 1996. The super foods that time (and men) forgot. Guide to Nutrition Foods, 11: 162164.

Wrobewski. J. 1986. High-sugar pumpkin as raw material for distilleries presumes. Fermencyjnyi Owocowo Warzy Wny. 30: 14-16 (C.F. FSTA 19, 1 H 111. J.)

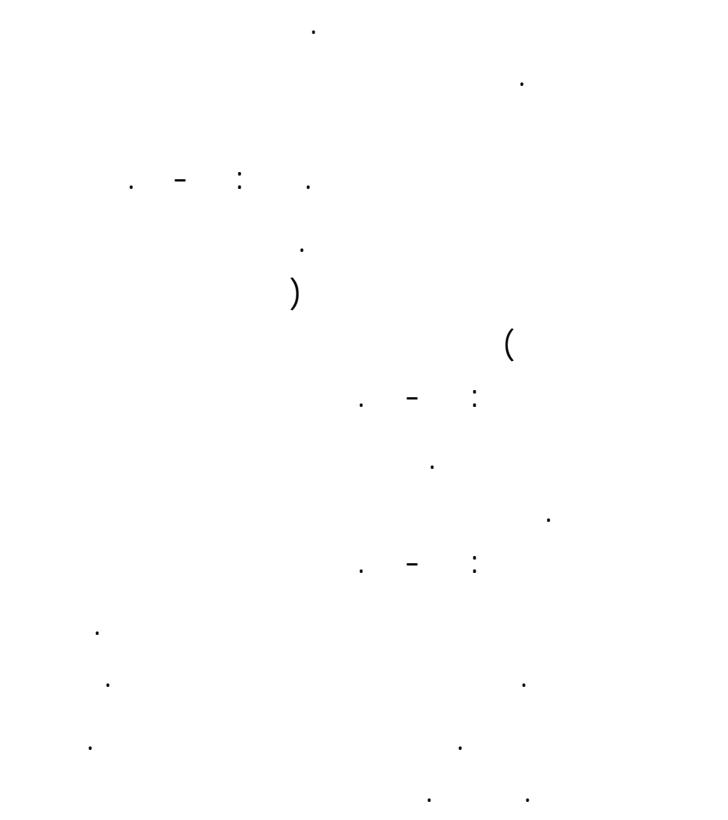

Al-Amoudi, N., Masoud, I., Feteih, R., \& Ardawi, M. 1996. Anthropometric measurements in school girls in the Western Region, Saudi Arabia. Saudi Medical Journal, 17(1): 26-31

Burri, B. 2003. United States Department of Nutrition Research Center (USDA) www.foodandhealthnetwork.com

Desobry, S., Netto, F. \& Iabuza, T. 1998. Preservation of $\tilde{\beta}$-carotene from carrots. Critical Reviews in Food Sci. and Nutrition, 5: 381-396.

\title{
ABSTRACT \\ THE EFFECT OF EDUCATION LEVEL ON FOOD PREFERENCE AND NUTRITION INFORMATION OF PRIMARY SCHOOL PUPILS IN SAUDI ARABIA KINGDOM
}

\author{
Suzan M. EI Zalaki \& Maria Talib Salim El Zahrane \\ Education Girls College for Home Economic in Makkah, K.S.A.
}

The present study was carried out to assess the effect of education level of primary schools pupils in Saudia Arabia kingdom, on their food preference and proper nutrition information. The age of the sample (200 pupils) ranged between 10-14 years. More than one third of the sample had family income higher than 9000 Saudi Riyals monthly. The parents with high education levels, were $79 \%$ of the fathers and $39 \%$ of the mothers. The high level of education of the parents, resulted in good knowledge and nutritional information of their childrens, and hence resulted in their avoidance to junk foods and snacks of low nutritive value.

Some food products, which were preferred by the pupils of the studied sample were produced, supplemented with pumpkins, as a source of carotenoids. The taste testing indicated that the products containing the pumpkins, namely; pizza, corn flakes, doughnuts, basbosa, and pies were of excellent acceptability. 